\title{
Measure Guideline: Installing Rigid Foam Insulation on the Interior of Existing Brick Walls
}

H. Natarajan, S. Klocke, and S. Puttagunta Consortium for Advanced Residential Buildings (CARB)

June 2012 


\begin{abstract}
NOTICE
This report was prepared as an account of work sponsored by an agency of the United States government. Neither the United States government nor any agency thereof, nor any of their employees, subcontractors, or affiliated partners makes any warranty, express or implied, or assumes any legal liability or responsibility for the accuracy, completeness, or usefulness of any information, apparatus, product, or process disclosed, or represents that its use would not infringe privately owned rights. Reference herein to any specific commercial product, process, or service by trade name, trademark, manufacturer, or otherwise does not necessarily constitute or imply its endorsement, recommendation, or favoring by the United States government or any agency thereof. The views and opinions of authors expressed herein do not necessarily state or reflect those of the United States government or any agency thereof.
\end{abstract}

Available electronically at http://www.osti.gov/bridge

Available for a processing fee to U.S. Department of Energy and its contractors, in paper, from:

U.S. Department of Energy Office of Scientific and Technical Information

P.O. Box 62

Oak Ridge, TN 37831-0062

phone: 865.576 .8401

fax: 865.576.5728

email: mailto:reports@adonis.osti.gov

Available for sale to the public, in paper, from:

U.S. Department of Commerce

National Technical Information Service

5285 Port Royal Road

Springfield, VA 22161

phone: 800.553 .6847

fax: 703.605 .6900

email: orders@ntis.fedworld.gov

online ordering: http://www.ntis.gov/ordering.htm 


\title{
Measure Guideline: Installing Rigid Foam Insulation on the Interior of Existing Brick Walls
}

\author{
Prepared for: \\ Building America \\ Building Technologies Program \\ Office of Energy Efficiency and Renewable Energy \\ U.S. Department of Energy \\ Prepared by: \\ Hariharan Natarajan, Steve Klocke, and Srikanth Puttagunta \\ Steven Winter Associates, Inc. \\ of the \\ Consortium for Advanced Residential Buildings (CARB) \\ 61 Washington Street \\ Norwalk, CT 06854 \\ NREL Technical Monitor: Cheryn Engebrecht \\ Prepared under Subcontract No. KNDJ-0-40342-02
}

June 2012 
[This page left blank] 


\section{Contents}

List of Figures

List of Tables

Definitions...

vii

Foreword....

Abstract.

Acknowledgements

....................

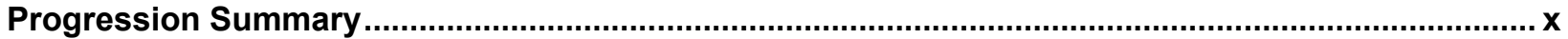

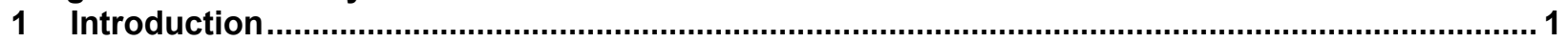

1.1 Methods of Insulating Existing Brick Masonry Buildings ...........................................1

1.1.1 Stud Frame and Fibrous Batt Insulation .........................................................2

1.1.2 Spray Polyurethane Foam Insulation ..............................................................2

1.1.3 Rigid Extruded Polystyrene (XPS) Board Insulation ......................................

1.1.4 Alternative Rigid Board Insulation Strategies ..................................................

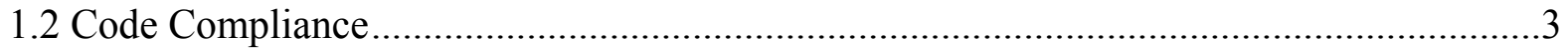

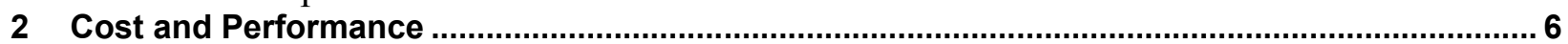

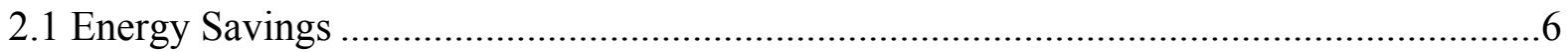

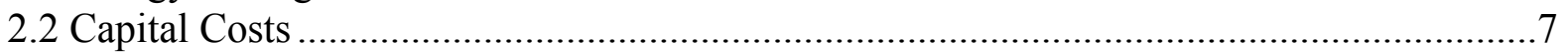

2.3 Indirect and Non-Energy Benefits .......................................................................

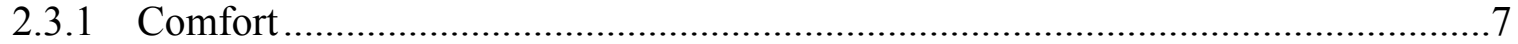

2.3.2 Indoor Air Quality........................................................................................

3 Overview of the Materials Utilized in the Installation of Insulation ........................................... 9

3.1 Extruded Polystyrene (XPS) Rigid Insulation Board ...............................................9

3.2 Foam Construction Adhesive and Applicator Gun ........................................................ 9

3.3 Low-expanding Foam Sealant and Applicator Gun............................................... 10

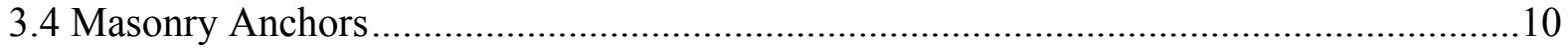

3.5 Colorless Water-Impermeable Coatings for Brick Masonry ....................................... 10

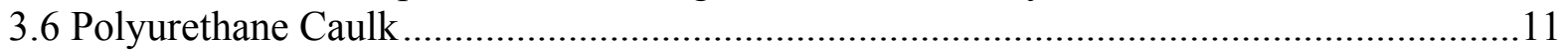

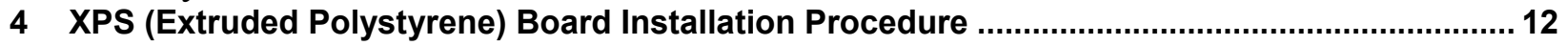

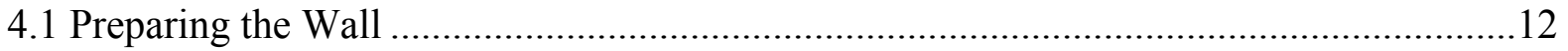

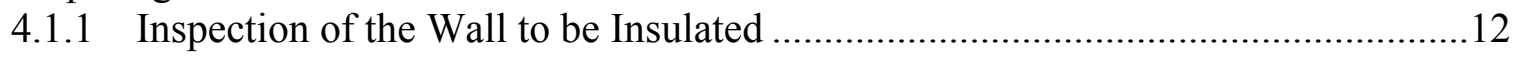

4.1.2 Rectification of Defects in Wall to be Insulated..............................................13

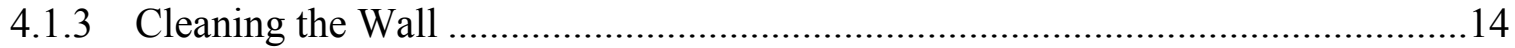

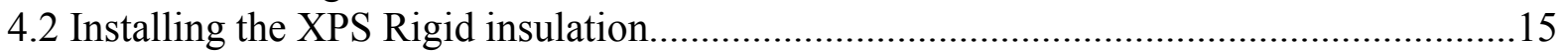

4.2.1 Adhering the XPS Rigid Insulation to the Wall................................................ 15

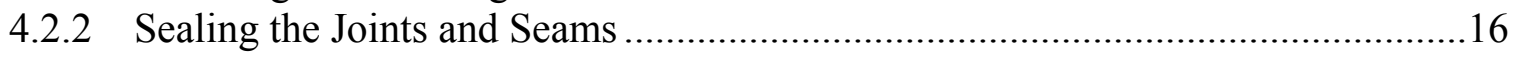

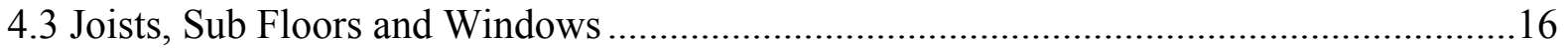

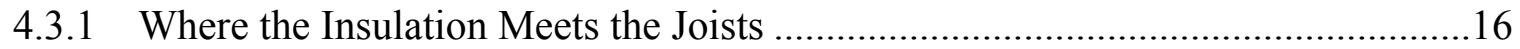

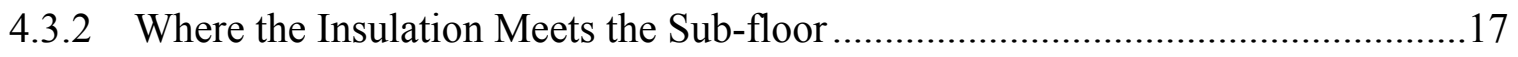

4.3.3 Where the Insulation Meets a Window............................................................ 17

4.3.4 Where the Insulation Meets an Existing Window .............................................18

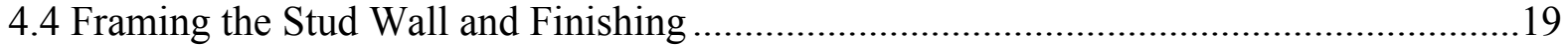

4.4.1 Framing Stud Walls After Insulation is Installed ........................................19

4.4.2 Installing Insulation Behind Existing Stud Wall .............................................19

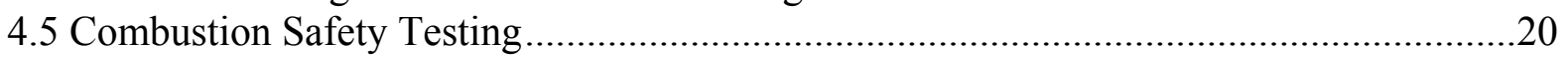

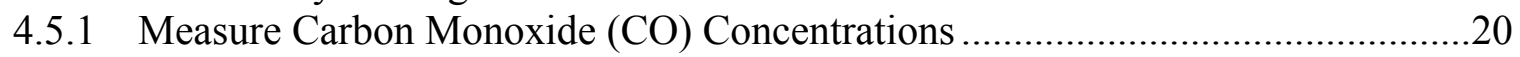

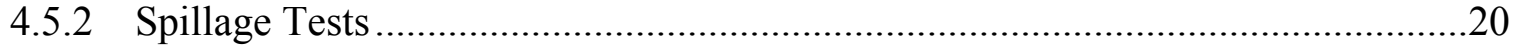

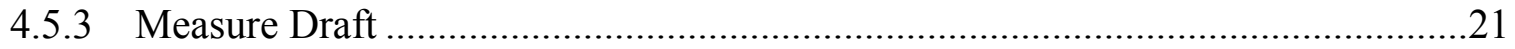


4.5.4 Worst Case Depressurization

4.5.5 Remedies for Combustion Problems ........................................................22

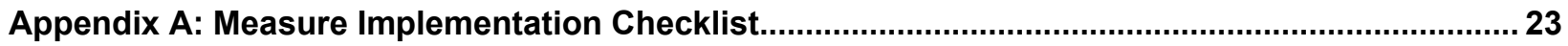

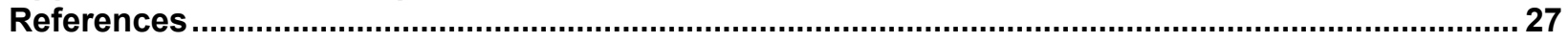




\section{List of Figures}

Figure 1. Stud frame and fibrous batt insulation ............................................................................ 2

Figure 2. Framed Stud wall spaced away from brick and polyurethane spray foam insulation......... 2

Figure 3. Stud frame and 2" XPS rigid insulation .............................................................................. 3

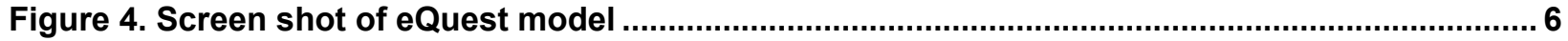

Figure 5. XPS used by Chesapeake Habitat for Humanity........................................................... 9

Figure 6. Low-expanding foam sealant and applicator ................................................................. 10

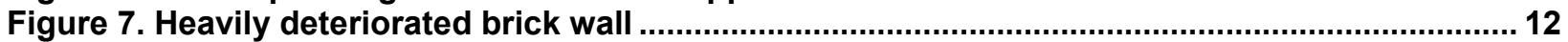

Figure 8. Knock off all debris, nails and plaster from wall ............................................................ 14

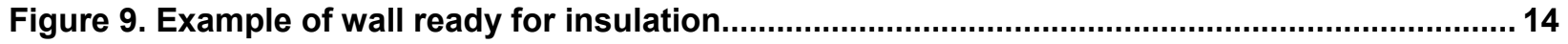

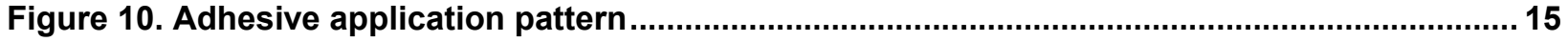

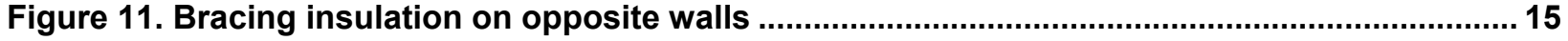

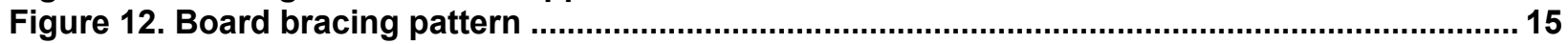

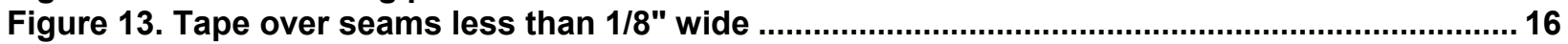

Figure 14. Use foam to seal all seams greater than $1 / 8$ " wide ....................................................... 16

Figure 15. Seal all penetrations through the rigid board with foam ................................................. 16

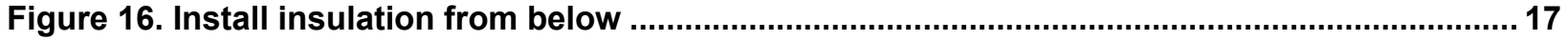

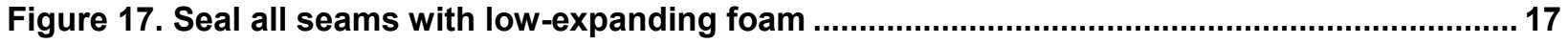

Figure 18. Rigid insulation extends past the sub-floor when installed from above ........................ 17

Figure 19. Installing a window after installing insulation and flashing. XPS insulation was placed between the window buck and the interior jamb extension (not yet installed) of this modular home.

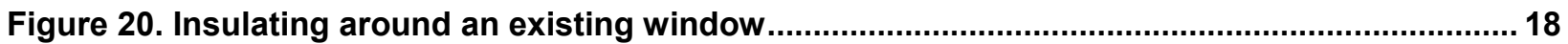

Figure 21. Slide insulation in behind existing stud wall ................................................................. 19

Figure 22. Spillage testing of an atmospherically vented, natural gas water heater........................20

Unless otherwise noted, all figures were created by CARB.

\section{List of Tables}

Table 1. Masonry Wall Insulation Requirements from 2009 IECC (Table 402.1.1).............................. 3

Table 2. Sample Insulation Strategy to Meet 2009 IECC (Table 402.1.1) Requirements.................... 4

Table 3. Masonry Wall Assembly Equivalent U-Value Requirements from 2009 IECC (Table 402.1.3) When More Than Half the Insulation is on the Interior....

Table 4. Modeled Savings from the Installation of Insulation for A 7,600 sq.ft. Multifamily Building 6

Table 5. Cost Range (Labor and Materials) and Simple Payback Period for Interior Insulating of

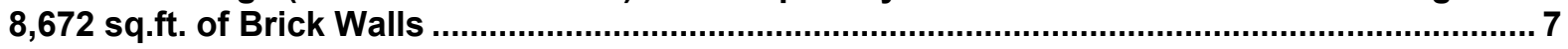

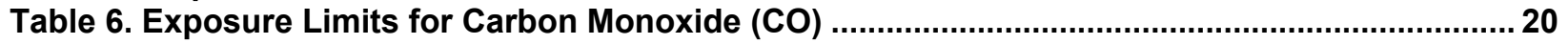

Table 7. Typical Draft Requirements for Combustion Equipment from BPI's "Technical Standard

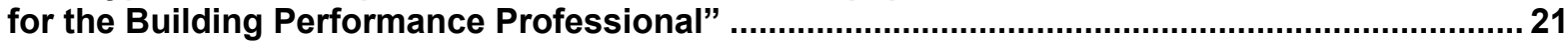

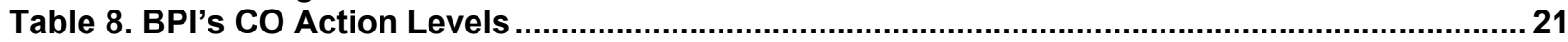

Unless otherwise noted, all figures were created by CARB. 


\section{Definitions}

ASHRAE American Society of Heating, Refrigerating and Air-

Conditioning Engineers

ASTM

American Society for Testing and Materials

BIA

The Brick Industry Association.

BLS

Bureau of Labor Statistics.

BPI

Building Performance Institute

EPA

US. Environmental Protection Agency

$\mathrm{HfH}$

Habitat for Humanity

HVAC

Heating, Ventilating, and Air Conditioning

IBC

International Building Code

IECC

International Energy Conservation Code

IRC

International Residential Code

MSDS

Material Safety Data Sheet

NREL

National Renewable Energy Laboratory

UL

Underwriters Laboratories, Inc. 


\section{Foreword}

The purpose of this document is to provide information on an effective method to insulate the interior of existing brick masonry walls with extruded polystyrene (XPS) insulation board. The document outlines step-by-step design and installation procedures while explaining the benefits and tradeoffs where applicable.

The authors intend that this document be useful to a varied audience that includes builders, remodelers, contractors and homeowners. Whenever a procedure requires specialized equipment or expertise, it is recommended those procedures be performed by persons qualified to do so, and possessing the necessary experience.

Throughout this document, the Consortium for Advanced Residential Buildings (CARB) team has included images and examples gained from working with various Habitat for Humanity (HfH) affiliates on multiple brick masonry retrofits. Though the procedures listed within this document have been selected with an eye toward the ease of execution by volunteers, typical of $\mathrm{HfH}$ construction, the concepts and methods discussed within this report are useful for anyone who intends to install rigid insulation on brick masonry walls. The primary goals for the methods described in this measure guideline are lowering the costs of execution and operation when retrofitting brick buildings, while maintaining or enhancing the overall safety, comfort, and durability.

\section{Abstract}

Rigid XPS foam board insulation is an easy-to-install and cost-effective solution when insulating the interior of brick masonry walls. When done correctly, with the boards secured flush against the brick wall, and the seams properly sealed and taped, the assembly acts as an air and water barrier. The boards can be adhered to the wall using both adhesives and/or masonry screws, and the cavities in the studded wall can be filled with extra insulation if required to meet code. Since the studs are never in direct contact with the brick wall, thermal bridging is minimized.

The procedure to install XPS insulation requires very little expertise and may be performed by homeowners and DIYers at low cost if existing conditions are ideal. If the existing brick shows signs of moisture or water intrusion, a qualified contractor should be used to rectify the brick assembly prior to insulating.

As an overall insulation strategy, rigid XPS board insulation is an attractive choice because of the low first costs, the ease of installation and the relatively significant energy savings accrued, when installed correctly. The payback period is reasonable, and the capital cost and the payback period may be minimized by subsidies and incentives provided by state/federal agencies and utility companies.

\section{Acknowledgements}

The authors would like to acknowledge the funding and support of the U.S. Department of Energy's Building America Program. This guide is the product of a collaborative effort. Special thanks to David Lee of the U.S. Department of Energy, Ren Anderson and Cheryn Engebrecht of the National Renewable Energy Laboratory, Matt Metzger of Habitat for Humanity of the Chesapeake, and Bill Bogdon of Habitat for Humanity NYC. 


\section{Progression Summary}

Check wall for -

- Cracked, Loose or Spalled bricks

- Deteriorated Mortar joints/Sealants

- Efflorescence

- Mold

- Lead paint
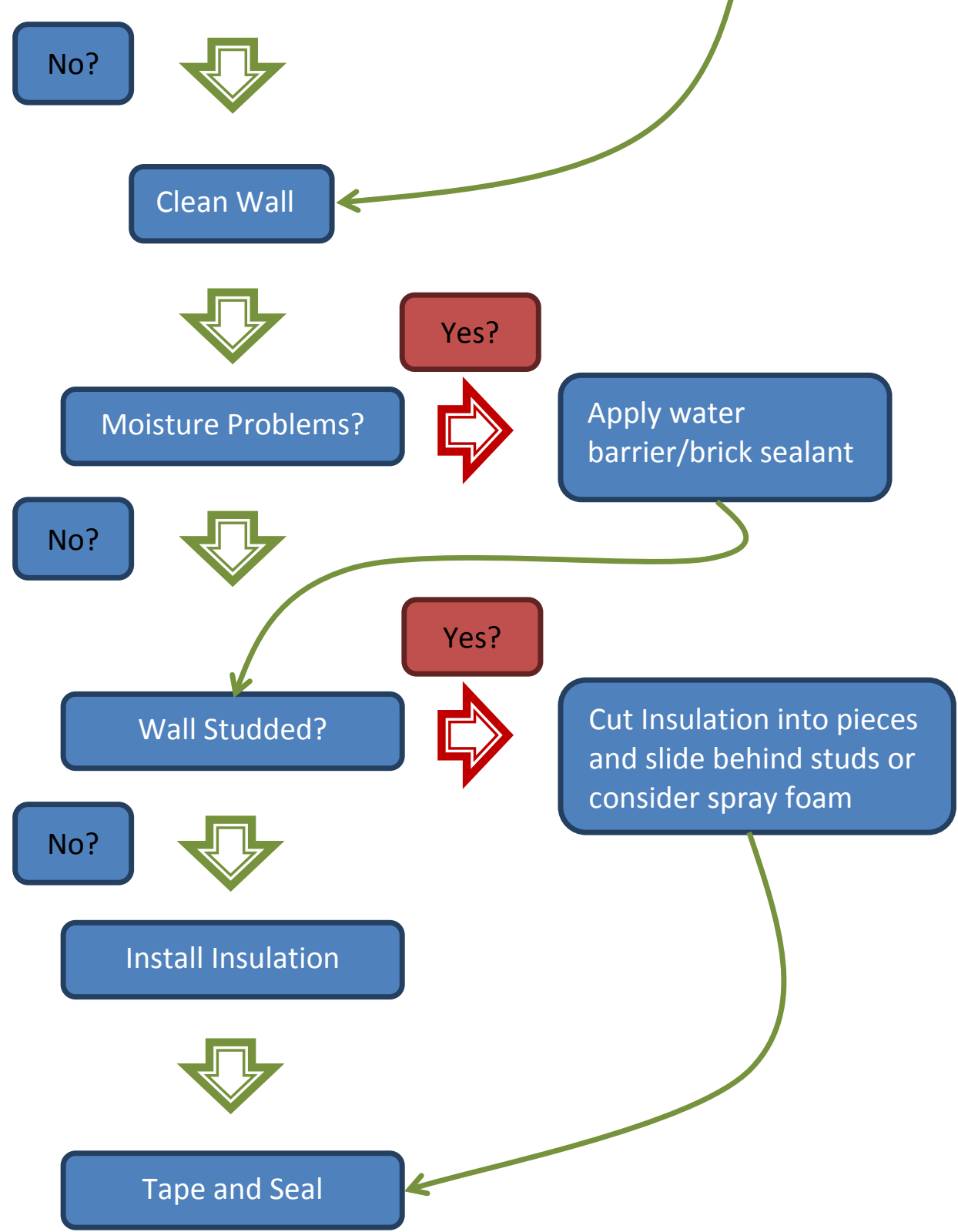


\section{Introduction}

Most of the current stock of load-bearing brick masonry buildings were built in the first half of the last century, for reasons ranging from the cost effectiveness to the durability of brick as a material. Much of this stock, when the owners choose to retrofit, upgrade, or convert, must be brought up to compliance with the currently enforced local building code. Many renovations of existing brick residential buildings are also being undertaken to meet compliance with green building programs. Regardless of the reason, retrofits are on the increase, and proper guidance is needed to help these projects achieve their goals, which generally align with the Building America Program's goal of reducing home energy use by 30\%-50\% (compared to pre-retrofit conditions for existing homes). Insulating these buildings is a key step towards the achievement of these objectives and a critical component of increasing home energy performance.

\subsection{Methods of Insulating Existing Brick Masonry Buildings}

Structures may be insulated from either the inside or the outside. Insulating from the outside generally results in greater durability (existing structure is protected) and higher airtightness (with a continuous exterior air barrier). However, this is not usually undertaken in brick structures as it tends to obscure the brick façade, which is a prime aesthetic concern, as well as a preservation requirement, if the building in question is a historic structure. A few different methods of varying effectiveness are commonly employed to insulate brick masonry structures from the inside.

By insulating the interior, the bricks will be exposed to harsher conditions (i.e. colder temperatures), which increases freeze-thaw potential and reduces drying potential. Therefore, for any interior insulation method, the exterior brick needs to be fully tuckpointed and an appropriate water drainage strategy for the load bearing brick walls is critical to prevent water/moisture from penetrating through the brick. If effective exterior water control and shedding cannot be properly established, insulating the interior surface of the brick wall should not be attempted. For strategies to establish exterior water control and shedding, refer to the following Building America report: "Measure Guideline: Internal Insulation of Masonry Walls". 


\subsubsection{Stud Frame and Fibrous Batt Insulation}

This is a very common, yet problematic insulation method, where a steel or wood stud wall is framed against the brick masonry and then filled with fiberglass batt insulation and finished with drywall. The primary issue with this type of installation is that there is a high probability of condensation and dampness in the fibrous batt, potentially leading to mold growth, and other health hazards. This method is not recommended under any circumstance.

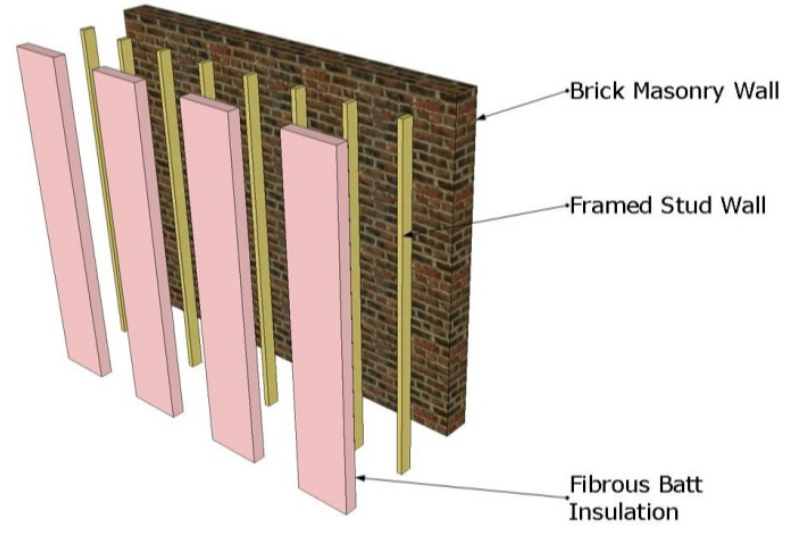

Figure 1. Stud frame and fibrous batt insulation

\subsubsection{Spray Polyurethane Foam Insulation}

In this strategy, closed-cell polyurethane foam is sprayed directly on to the brick masonry. This is the most effective, though costly, method for insulating the interior of brick walls. Framing should be held back an inch or two from the masonry wall in order for the foam to adhere directly to the masonry and reduce thermal bridging. This whole assembly is finished with drywall to the face of the studs. Closed-cell spray polyurethane foam forms a very effective air and water barrier, and this method of insulation provides excellent airtightness to the insulated portion of the envelope. The procedure requires expertise and certain specialized tools and equipment, and is usually contracted to

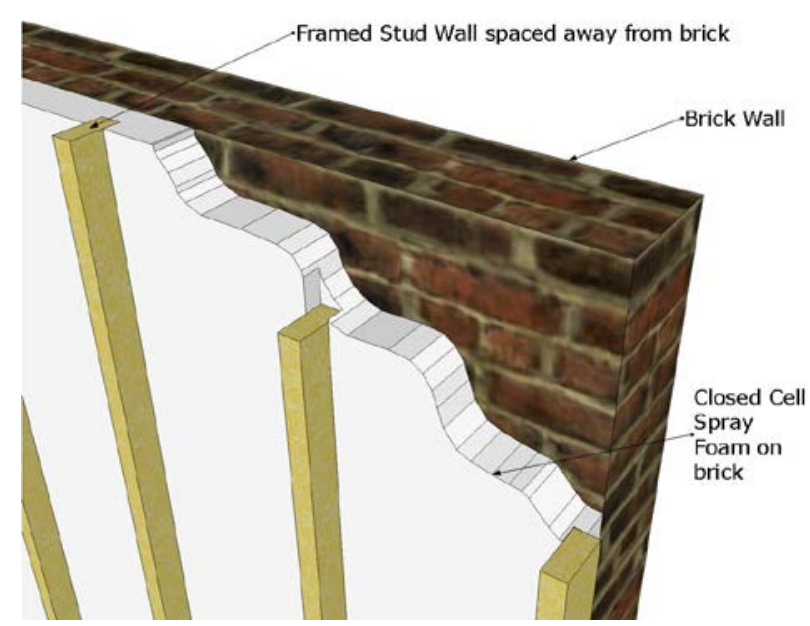

Figure 2. Framed Stud wall spaced away from brick and polyurethane spray foam insulation specialists.

\subsubsection{Rigid Extruded Polystyrene (XPS) Board Insulation}

This method is relatively easy to implement and consists of rigid foam insulation board directly adhered to the masonry wall, finished off by studs and drywall. When installed correctly, the taped and sealed foam is an effective air barrier.

Two-inch XPS that is rated for moist or below grade applications is recommended in colder climates (Climate Zone 4 and higher), as it is a more durable product. If additional insulation is required, the cavities in the stud wall may be filled with fibrous insulation as illustrated later in this document. The application of a liquid-applied air barrier to the inside of the masonry before the installation of insulation can be an advantageous back-up measure. 
Untreated brick has measurable air leakage, therefore, for this strategy to be successful, the interior brick surface needs to be even to allow for complete and uniform adhesion of the XPS boards to the brick. If the interior wall surface is uneven, it is recommended that a liquid-applied air barrier be applied prior to the XPS, or closed-cell spray polyurethane foam (as discussed in Section 1.1.2) be applied instead.

This method of insulation has been selected for this measure guideline due to its cost effectiveness, and will be dealt with exclusively in the rest of this document.

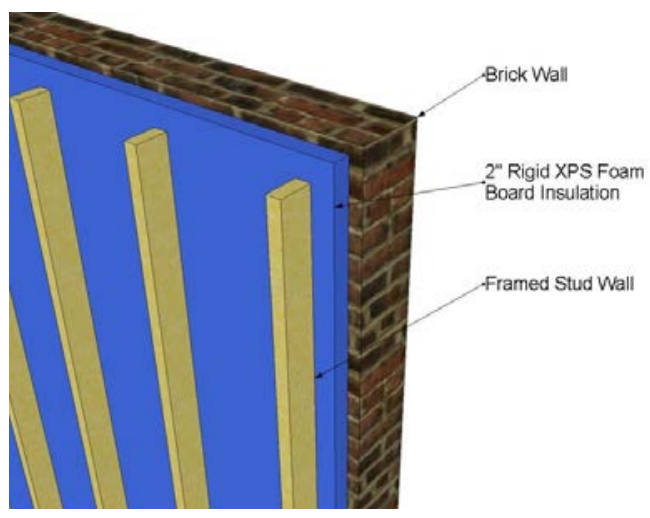

Figure 3. Stud frame and 2" XPS rigid insulation

\subsubsection{Alternative Rigid Board Insulation Strategies}

Two other materials that are often used for insulating walls include:

1. Rigid Expanded Polystyrene (EPS) Board Insulation - Also known as bead-board, this is the most inexpensive form of rigid insulation available, but is not as suitable as XPS for insulation purposes as it is deficient in a few key areas: EPS has a lower R-value per actual inch of thickness (ranges from R-3.5 to R-4 per inch), is weaker and more prone to damage while handling, and is the most vapor-permeable type of rigid foam. Rigid EPS is not recommended as a material to insulate the interior of brick masonry walls.

2. Polyisocyanurate (Polyiso) Board Insulation - Polyiso boards are polyurethane boards that possess improved strength, thermal resistance and moisture-retardant properties over both EPS and XPS insulation boards. Polyiso boards are usually available foil-faced (with aluminum) and show an R-value of ranging from R-6 to R-7 per inch. They are typically the most expensive of the rigid insulation materials available, but prices fluctuate, so this can be a viable alternative based on local pricing at the time of construction.

\subsection{Code Compliance}

The 2009 International Energy Conservation Code (IECC) provides minimum insulation requirements for masonry walls that vary across geographically differentiated climate zones (IECC, 2009).

Table 1. Masonry Wall Insulation Requirements from 2009 IECC (Table 402.1.1)

\begin{tabular}{cc}
\hline Climate Zone & Mass Wall Insulation R-Value \\
\hline 1 & 3 exterior / 4 interior \\
2 & 4 exterior / 6 interior \\
3 & 5 exterior $/ 8$ interior \\
4 except Marine & 5 exterior $/ 10$ interior \\
5 and Marine 4 & 13 exterior $/ 17$ interior \\
6 & 15 exterior $/ 19$ interior \\
7 and 8 & 19 exterior $/ 21$ interior \\
\hline
\end{tabular}

(The R-value after the slash applies when more than half of the insulation is on the interior of the mass wall -it is the minimum $R$-value applicable to all cases in this document) 
If retrofitting a brick building that needs to comply with the insulation requirements of the 2009 IECC, the climate zone appropriate to the location of the structure must be determined, and then the applicable R-value from Table 1 will dictate the level of insulation needed for the building.

If using rigid foam board insulation, meeting code can be accomplished with various thicknesses of XPS board, which can then be supplemented with other forms of insulation as required by the specific climate zone. Minimum thicknesses listed in the table below may not be available from all manufacturers; the table represents just one example of meeting code requirements using XPS board.

Table 2. Sample Insulation Strategy to Meet 2009 IECC (Table 402.1.1) Requirements

\begin{tabular}{|c|c|}
\hline Climate Zone & Rigid Board Insulation Strategy \\
\hline 1 & $1 "$ of XPS Board \\
\hline 2 & $1.25 "$ of XPS Board \\
\hline 3 & $1.75 "$ of XPS Board \\
\hline 4 except Marine & 2" of XPS Board \\
\hline 5 and Marine 4 & $\begin{array}{l}2 \text { " of XPS Board + R-13 Fiberglass Batt } \\
\text { insulation in cavity of studded wall }\end{array}$ \\
\hline 6 & $\begin{array}{l}2 " \text { of XPS Board + R-13 Fiberglass Batt } \\
\text { insulation in cavity of studded wall }\end{array}$ \\
\hline 7 and 8 & $\begin{array}{l}\text { 2" of XPS Board + R-13 Fiberglass Batt } \\
\text { insulation in cavity of studded wall }\end{array}$ \\
\hline
\end{tabular}

Alternatively, rather than following the above prescriptive requirements, Table 402.1.3 of IECC 2009, as shown below, can be used. This method would include computing the Uvalue of the proposed insulated brick wall assembly, and ensuring that it does not exceed the values from Table 402.1.3. This approach may result in a different insulation requirement than if following the prescriptive requirements; however, meeting the requirements of either table ensures compliance.

Table 3. Masonry Wall Assembly Equivalent U-Value Requirements from 2009 IECC (Table 402.1.3) When More Than Half the Insulation is on the Interior

\begin{tabular}{cc}
\hline Climate Zone & Mass Wall U-Factor \\
\hline 1 & 0.170 \\
2 & 0.140 \\
3 & 0.120 \\
4 except Marine & 0.100 \\
5 and Marine 4 & 0.082 \\
6 & 0.060 \\
7 and 8 & 0.057 \\
\hline
\end{tabular}

Typically, the U-Value requirements are less restrictive than the R-Value requirements, for most climate zones. 


\section{Critical Takeaways}

- This technique should only be used on sound, clean, and dry brick masonry walls.

- Most renovations, remodels, and additions are governed by code, and thus these buildings must be brought to compliance.

- In many states, the insulation requirements are determined by Tables 402.1.1 or 402.1.3 of the International Energy Conservation Code (IECC) 2009.

- 2" XPS is the recommended starting level for insulating brick walls in Climate Zones 4 and higher. 


\section{Cost and Performance}

\subsection{Energy Savings}

We may reasonably assume brick masonry has an R-value of $\mathrm{R} \sim 1$ for every 8 " thickness (BIA,1997). Due to the relatively low insulating property of brick masonry, the addition of 2" of XPS board (an insulation value of R-10) can dramatically increase the performance of the building. To demonstrate the energy savings of this insulation, CARB constructed a whole building energy model in eQuest v3-64 energy modeling software, and simulated the electricity and natural gas consumption before and after the addition of insulation for a period of one year. eQuest was used, since the BA preferred software, BEopt, does not possess the ability to model structural brick buildings.

The building modeled was a 7,600 sq.ft. multifamily building, with eight apartments of approximately 950 sq.ft. each. The total area of wall covered by the new insulation was 8,672 sq.ft. The modeled building was located in New York City, in Climate Zone 4.

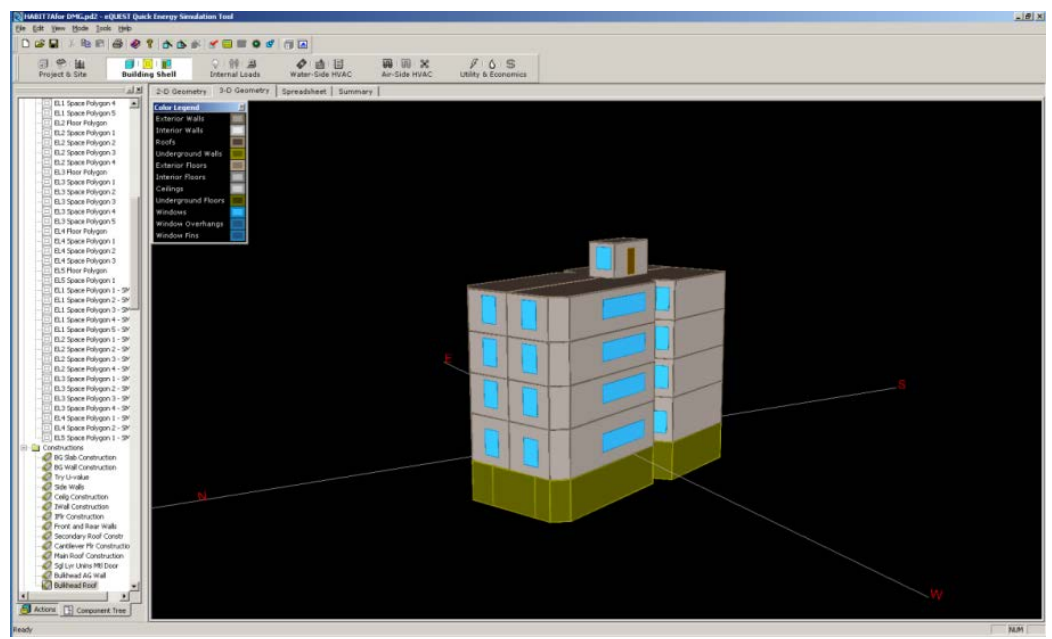

Figure 4. Screen shot of eQuest model

Significant savings were realized in heating bills after the installation of rigid XPS insulation. The energy and fuel consumption of the modeled building, both before and after the installation of insulation, is shown in Table 4, where reductions of $1 \%$ in the electricity consumption and $13 \%$ in gas consumption over a period of one year for the entire building were predicted. The simulated utility cost savings were about $\$ 388$ annually for electricity (cooling) and $\$ 1,686$ annually for gas (heating), a combined savings of about $\$ 2,074$ a year.

Table 4. Modeled Savings from the Installation of Insulation for A 7,600 sq.ft. Multifamily Building

\begin{tabular}{c|c|c|c|}
\hline & $\begin{array}{c}\text { Pre-retrofit } \\
\text { (No Insulation) }\end{array}$ & $\begin{array}{c}\text { Post-retrofit } \\
\text { (R-10 XPS) }\end{array}$ & $\begin{array}{c}\text { Annual Savings } \\
\text { (USD) }\end{array}$ \\
\hline $\begin{array}{c}\text { Annual Electricity } \\
\text { Consumption } \\
\text { (kWh) }\end{array}$ & 52,480 & 50,450 & $\$ 388$ \\
$\begin{array}{c}\text { Annual Gas } \\
\text { Consumption } \\
\text { (Therms) }\end{array}$ & 10,564 & 9,216 & $\$ 1,686$ \\
\hline
\end{tabular}

(Electricity costs were assumed to be $\$ 0.191 / \mathrm{kWh}$ and gas costs $\$ 1.251$ therm.)(BLS, 2011) 


\subsection{Capital Costs}

The analysis above shows a potential 9\% reduction in energy costs from the installation of R-10 insulation. This equates to an annual savings of approximately \$260/apartment unit. Although those savings can be realized using various insulating materials, rigid XPS can be a fairly low first-cost strategy during construction or renovation that provides an excellent return on investment. NREL's National Residential Efficiency Measures Database provides cost ranges for the installation of rigid foam wall insulation. Though estimated for installation on the exterior, the costs are almost identical to interior installation situations assuming the interior is already gutted and intended to be finished out with framing and drywall. Table 5 summarizes the installed costs for this multifamily building and the simple payback for this measure. It should be noted that the 2" of XPS has a lower R-value than the other two insulating measures. The reduced potential energy savings due to lower R-value is accounted for in the simply payback analysis.

Table 5. Cost Range (Labor and Materials) and Simple Payback Period for Interior Insulating of 8,672 sq.ft. of Brick Walls

\begin{tabular}{c|c|c|c}
\hline Measure & $\begin{array}{c}\text { Installation Costs } \\
\text { (Per ft }^{2} \text { ) }\end{array}$ & $\begin{array}{c}\text { Installed Cost for } \\
\text { Modeled Building }\end{array}$ & $\begin{array}{c}\text { Simple Payback } \\
\text { Period (Years) }\end{array}$ \\
\hline $\begin{array}{c}\text { XPS, 2", R-10 } \\
\text { Closed-Cell Spray }\end{array}$ & Range of $\$ 0.95-\$ 1.30$ & $\$ 8,238-\$ 11,274$ & $4.0-5.4$ \\
$\begin{array}{c}\text { 2", R-12 } \\
\text { Polyiso, 2", R-12 }\end{array}$ & Range of $\$ 1.80-\$ 2.25$ & $\$ 15,609-\$ 19,512$ & $7.5-9.4$ \\
\hline
\end{tabular}

\subsection{Indirect and Non-Energy Benefits}

The installation of insulation directly reduces the thermal loads in the building; as a result, HVAC systems can be sized smaller to satisfy the new smaller loads. Correctly installed rigid insulation is an air barrier, reducing infiltration and also the amount of heating and cooling required, further aiding in the downsizing of HVAC equipment. This indirect benefit can be realized if HVAC replacements are part of the scope of the retrofit. Besides these energy and first cost savings, the potential non-energy benefits from installing insulation on the interior of brick masonry walls are improved comfort and indoor air quality.

\subsubsection{Comfort}

Insulated spaces cool and warm faster, and stay cool and warm longer than uninsulated spaces. Maintaining thermal comfort within the insulated space becomes easier and more straightforward as drafts are minimized, and finer control over temperature and humidity becomes possible.

\subsubsection{Indoor Air Quality}

A reduction in infiltration helps maintain air quality in the space, and reduces the chances of external contaminants entering the home. However, controlled mechanical ventilation should be added to any substantially airtightened building in order to ensure acceptable indoor air quality. 


\section{Is mechanical ventilation needed?}

Infiltration testing with a blower door should be performed at the completion of the energy efficiency measure. Results from this testing should be used to determine if additional mechanical ventilation is required according to the ASHRAE 62.2 ventilation standard.

1. Calculate the required mechanical ventilation rate for the home from ASHRAE 62.2. CFM design

$$
\begin{aligned}
& \text { CFM design }=0.01 \times \mathrm{FA}+7.5\left(\mathrm{~N}_{\mathrm{br}}+1\right) \\
& \text { Where FA = finished floor area and } \mathrm{N}_{\mathrm{br}}=\# \text { of bedrooms }
\end{aligned}
$$

2. From the infiltration testing, determine the CFM50 number for the building.

3. Use the Sherman-Grimsrud air infiltration model (Sherman M. 1987. Estimation of Infiltration for Leakage and Climate Indicators. Energy and Buildings, 10, p.81.) to estimate infiltration under natural conditions. $\mathrm{CFM}_{\text {nat }}$ (here is a reference for how to determine this value: http://www.homeenergy.org/show/article/nav/blowerdoor/id/1015)

4. Divide $\mathrm{CFM}_{\text {nat }}$ by conditioned square footage. CFM $\mathrm{Cat}_{\mathrm{nat}} / \mathrm{ft}^{2}$

5. Is the $\mathrm{CFM}_{\text {nat }} / \mathrm{ft}^{2}$ value less than 0.02 ? If yes, use the ASHRAE 62.2 value for ventilation. You cannot reduce the mechanical ventilation rate.

6. If the CFM nat $/ \mathrm{ft}^{2}$ value is greater than 0.02 , perform the following calculation to determine how much mechanical ventilation you need.

$$
\mathrm{CFM}_{\text {needed }}=\mathrm{CFM}_{\text {design }}-\left[1 / 2 \times\left(\mathrm{CFM}_{\text {nat }} / \mathrm{ft}^{2}-0.02\right) \times \mathrm{FA}\right)
$$

\section{Critical Takeaways}

- The addition of insulation reduces energy consumption, utility bills, and size of HVAC equipment needed, as well as likely increasing comfort and indoor air quality.

- In most cases, the installation of rigid insulation has a lower capital cost than closed cell spray polyurethane foam insulation.

- The payback period on the installation of rigid insulation is usually very reasonable.

- Precaution: When reducing the natural air exchange of a home, there is a potential need for mechanical ventilation depending on the level of air tightness. 


\section{Overview of the Materials Utilized in the Installation of Insulation}

\subsection{Extruded Polystyrene (XPS) Rigid Insulation Board}

Rigid XPS boards for building insulation are typically available in 2' ${ }^{\prime} 8$ ' and 4'x8' sizes, in thicknesses between 0.5 " to 2 ". Most codes usually require a thermal ignition barrier (2009 IRC Section R316.4) and thus XPS board cannot be left exposed indoors except in special cases. The boards are usually available with butt or shiplap edges to aid in ensuring a tight air-seal during installation.

- R-value: $5 \mathrm{ft}^{2} \mathrm{~h}^{\circ} \mathrm{F} / \mathrm{Btu}$-in (R-5/inch)

- Air barrier: Yes

- Vapor retarder: Typically Class II (1.2 Perm-inch, ASHRAE 1997)

XPS board is commonly used on the outside of residential above-grade walls, and on the inside and outside of foundation walls.

\subsection{Foam Construction Adhesive and Applicator Gun}

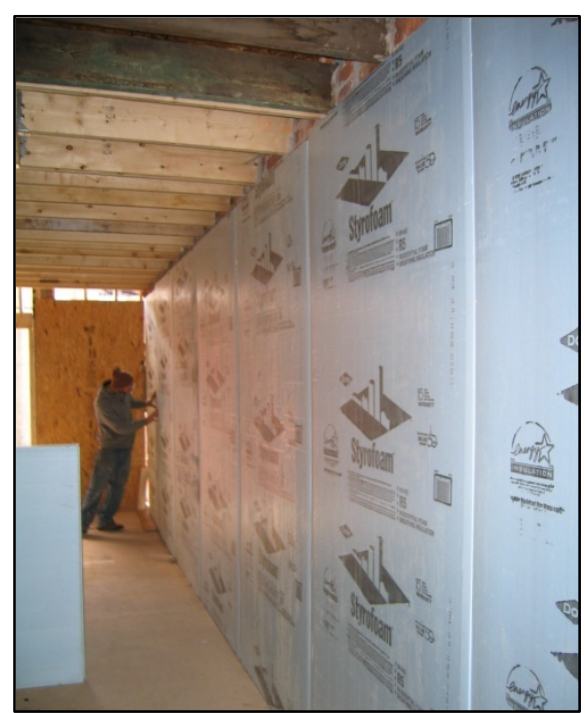

Figure 5. XPS used by Chesapeake Habitat for Humanity

Foam construction adhesives used to adhere the foam board to the brick masonry, are usually aerosol-propelled, moisture-curing polyurethane adhesives. They can be used on plywood, lumber, OSB, fiberglass, foam board, and most other construction materials, and are applied using a special purpose gun applicator. The advantages of using foam adhesive over traditional construction adhesive are:

- Low cost - One can of foam adhesive is usually the equivalent of 10 to 20 quart tubes of standard construction adhesive, depending on bead thickness. Overall, the cost of the can, gun and cleaner are cheaper than the equivalent amount of quart tubes of construction adhesive.

- Efficient application - The use of the gun allows for accurate and efficient application of the foam to the board. The gun needs to be cleaned regularly and stored with the cleaner can between uses to prevent clogging.

When working with foam sealants and foam adhesives, recognize that some of the sealant and adhesive materials can be hazardous if not handled properly. Refer to the Material Safety Data Sheets (MSDS) for all chemical products used. Use appropriate personal protective equipment including respirators, safety glasses, kneepads, and disposable protective clothing as appropriate. 


\subsection{Low-expanding Foam Sealant and Applicator Gun}

Similar to foam construction adhesives, low-expanding foam sealants are usually aerosolpropelled, moisture-curing urethane foams that are used to air-seal insulation board joints, edges and gaps. The foam expands in place and bonds to seal and stop the passage of air, gases and water. The foam can be used on plywood, lumber, OSB, fiberglass, foam board and most other construction materials, and is applied using a special purpose gun applicator. The advantages of using low-expanding foam sealant are:

- Low Cost - One 12 ounce can of foam sealant usually provides the equivalent of 1,200 linear feet of a $1 / 2$ " bead of sealant.

- More Efficient Application - The use of the gun allows more accurate and efficient application of the foam to the board, and reduces waste from storage and transport. The gun needs to be cleaned regularly and stored with the cleaner can on between uses to prevent

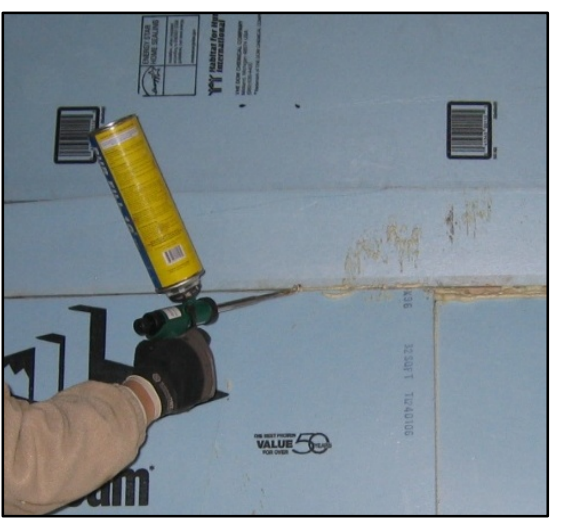

Figure 6. Low-expanding foam sealant and applicator clogging.

Once applied, the foam is tack-free in 10 minutes and trimmable (for finishing purposes) in about 30 minutes. The cured foam resists age-hardening, solvents, and water, but will deteriorate if exposed to direct sunlight.

\subsection{Masonry Anchors}

Masonry anchors are usually screw-type devices used to secure different materials and components to brick and concrete. There are many kinds of masonry anchors, but the ones most applicable to the installation of rigid insulation on the inside of brick masonry are concrete screws. These are basically stainless steel or coated screws that cut their own thread into the brick, when driven into the masonry. They are highly resistant to rust and provide excellent holding to the brick. When choosing screw lengths, make sure that the screw embeds itself at least 1 " into the masonry after going through all the components that need to be adhered to the wall.

\section{Helpful Tip}

Be sure to use the correct drill bit size specified by the screw manufacturer when screwing masonry screws into walls.

\section{Length of screw required $=$ Thickness of material being anchored +1 " 1.5 "} (Embedment Depth)

\subsection{Colorless Water-Impermeable Coatings for Brick Masonry}

Colorless coatings are used on brick masonry to create vapor-permeable but air and water resistant barriers. These applied barriers must be used after a thorough inspection of the cleaned brick surface for water penetration issues.

Colorless coatings for brick are of two types:

- Film-forming coatings - These form a film on the surface of the brick and help prevent leaks. They are available as acrylics, stearates, mineral gum waxes, and urethanes. 
- Penetrants - These penetrate the surface of the brick to depths up to $3 / 8$ ", and prevent water penetration by changing the capillary force of the brick surface from positive (suction) to negative (repulsion).

Colorless coatings of both kinds are rendered ineffective if there are cracks present in the brick that are greater than 0.02 " wide. Therefore, the brick MUST be inspected and the cracks remedied before the application of the coatings.

\subsection{Polyurethane Caulk}

Tube-applied polyurethane caulk is an acceptable alternative to the gun-propelled polyurethane foam adhesive for use on rigid foam board. Polyurethane caulk adheres well to most substrates, and cures relatively quickly. 


\section{XPS (Extruded Polystyrene) Board Installation Procedure}

The following instructions set out general procedures for the installation of XPS rigid insulation on the interior of brick masonry walls. Keep in mind the following:

- When using specialized equipment such as the gun applicator for the adhesive foam, follow all manufacturer-supplied instructions and precautionary measures.

- Use the appropriate safety equipment, such as gloves and goggles, when performing certain procedures, such as the application of adhesive or foam sealant.

- Refer to Appendix A for an installation checklist to follow in the field.

\subsection{Preparing the Wall}

There are three stages to the preparation of the wall for the installation of rigid insulationinspection, rectification and cleaning.

\subsubsection{Inspection of the Wall to be Insulated}

Before the installation of insulation, the brick masonry wall must be inspected for the following defective conditions (BIA, 2005). If any are found to exist, DO NOT proceed with the installation of insulation until the defective conditions are rectified. All these conditions may be exacerbated by the addition of insulation, and the potential for health and safety hazards may be greatly increased.

- Cracked bricks

- Loose bricks

- $\quad$ Spalled bricks

- Hairline cracks in mortar

- Deteriorated mortar joints

- Deteriorated or torn sealants

- Out-of-plumb (non-vertical, sagging wall)

- Efflorescence (salts left on brick by evaporation - indicative of water path through brick)

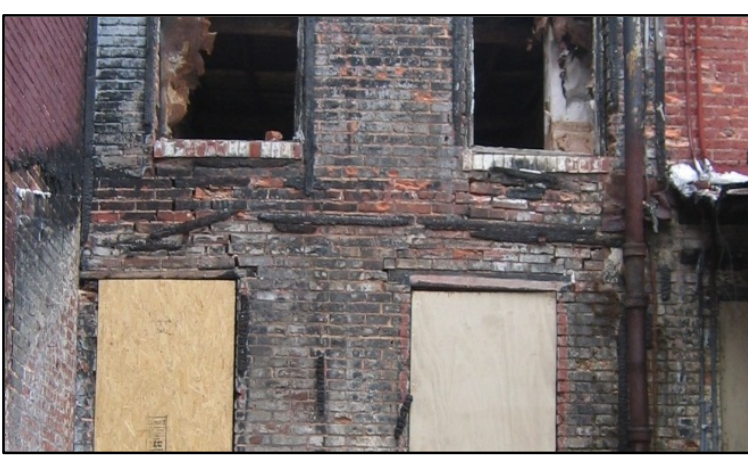

Figure 7. Heavily deteriorated brick wall

- Staining

- Water penetration (check for dampness on the interior)

- Mold

- Lead paint. 


\subsubsection{Rectification of Defects in Wall to be Insulated}

The following are general guidelines for the determination and correction of existing defects in the brick wall prior to the application of insulation. Again, insulation MUST NOT be installed unless these defects are corrected. As many of these repairs are beyond the scope of this document, references have been provided for those interested in a deeper investigation of these topics:

1. Cracked, loose and spalled bricks (BIA, 2005) - These bricks must be replaced. The bricks to be replaced must be cut out without affecting the bricks around them. The wall must be dampened, and then the replacement bricks must be 'buttered' with mortar and then centered in the cavities, also 'buttered' with mortar. After the mortar is 'thumbprint' hard, the joints can be tooled as desired.

2. Hairline cracks in mortar/deteriorated mortar joints (BIA, 2005)- The damaged mortar must be removed, and the joints must be repointed. This is specialized work and it is recommended that an expert be contracted to perform this work, especially on historic masonry buildings (Robert and Speweik, 1998). Repointing with incorrectly selected mortar may result in damage to the masonry materials (NPS, 1998).

3. Deteriorated/torn sealants (BIA, 2006) - Remove deteriorated sealants without damaging adjacent brickwork, prime, and reseal. For further information, see ASTM C 1193, Guide for Use of Joint Sealants.

4. Efflorescence and staining (BIA, 2006) - Repair any leaks before cleaning efflorescence (usually washing with water after repair mortar has dried, and then rubbing with a stiff brush.) (Merrigan, 1986) Staining may be removed by a poultice, after determining the cause of the stain. If the stain damage is only cosmetic, it may be ignored as the insulation will be installed over the brickwork and will completely obscure the stain from view.

5. Water penetration - Check for dampness on the wall to be insulated (interior). Any dampness is a sign of more serious problems and indicative of moisture transport across the wall (Straube et al 2011), from the outside to the inside. Allow the brick to dry out, address any bulk water penetration issues, and then apply a waterproof membrane or brick sealant. Allow to dry/cure before installing insulation. Repeat check after cleaning wall.

6. Mold - If less than 1 sq.ft. of mold is found on the surface of the wall, simple remedies are available. Soak the wall with water and then spray the mold directly with a solution of bleach and water. Then brush out with a stiff brush. Repeat until no more mold is visible. Once all mold is gone, wash surface with warm water, then spray and soak surface with vinegar to kill subsurface mold. Allow the affected part 
of the wall to dry completely before installing insulation. Do not forget to use facemasks and gloves when cleaning out mold. The presence of mold indicates the existence of a moisture problem, which must be investigated after the mold has been removed. If the cause of the mold cannot be identified and/or if the mold growth is greater than one square foot, it is recommended to hire a mold consultant specializing in building assessments to evaluate the entire home. For more detail on mold causes and remediation see "Preventing Mold/Moisture Problems" (CARB)

7. Lead paint - This is a serious health hazard usually found in historic homes and homes of a certain vintage. Lead paint removal requires specialized equipment and expertise and should not be performed by volunteers. If lead paint is suspected, work must not continue until the situation is remedied by specialists. Refer to EPA's website on lead for further detail (www.epa.gov/lead).

In addition to evaluating the condition of the walls prior to retrofit, check to see if any combustion equipment exists in the space to be insulated that does not source its combustion air from the outside. If atmospheric combustion appliances exist within the space, combustion safety testing is required (see Section 4.5). If combustion appliances are being replaced, specify sealed combustion equipment.

\subsubsection{Cleaning the Wall}

Not all brick interiors are exposed, and most projects will encounter walls covered in plaster or some other material. To ensure proper adhesion of insulation to the wall, and to prevent any air gaps that may occur and create convective loops, the wall must be cleaned of all debris, nails and plaster. The wall does not have to be perfectly smooth, but smooth enough that no significant air gaps are formed between the insulation and the wall that can harbor convective loops that transport moisture.

1. Knock off all nails, debris and plaster with a hammer and chisel (if required).

2. If a large area of the wall is covered by plaster that cannot be removed by hand, then consider the removal of plaster by soaking, scraping and pressure-washing (above 1,500 psi). The use of muriatic acid solutions are not recommended as they tend to damage and discolor the brick, an important consideration when dealing with historic buildings. Both these methods are a last resort, and should only be performed by experts with the necessary equipment.

3. Allow wall to dry completely before proceeding.

4. Inspect walls again after cleaning, following steps in 4.1.2.

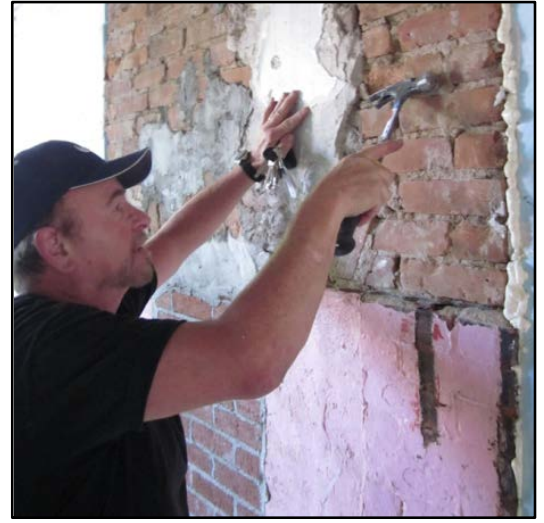

Figure 8. Knock off all debris, nails and plaster from wall

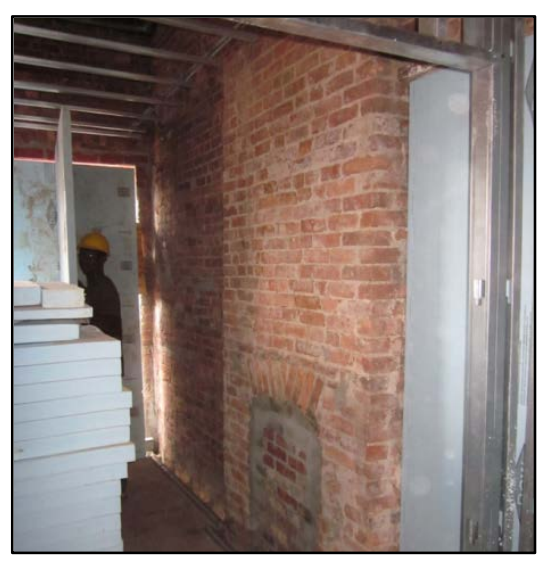

Figure 9. Example of wall ready for insulation 


\subsection{Installing the XPS Rigid insulation}

The installation of the XPS board occurs in a couple of steps: adhering the board to the wall, and sealing or taping the seams.

\subsubsection{Adhering the XPS Rigid Insulation to the Wall}

When possible, use the entire 2'x8' or 4'x8' sheet of rigid insulation.

1. Prepare the applicator gun and adhesive as per the manufacturer's instructions.

2. Apply a $1 / 2$ ' bead of foam along the perimeter of the board and as an ' $X$ ' across the center. A serpentine application across the board is also an acceptable alternative to the ' $X$ '.

3. Apply the rigid insulation to the predetermined wall surface. Make sure to apply continuous pressure to the rigid board. Moving the board repeatedly will reduce the adhesion of the board to the wall.

4. Place a $2 \times 4$ brace against the seam of the rigid insulation boards and secure until the binder

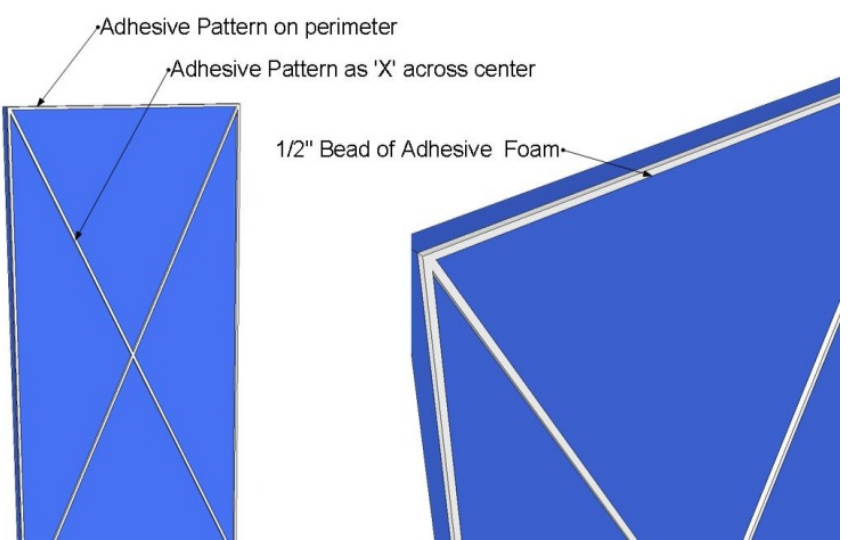

Figure 10. Adhesive application pattern is fully cured. At the Habitat for Humanity projects, extension poles braced against an opposing wall were used to hold the wood and rigid insulation in place. The narrow configuration of these rowhouses allowed for this bracing method.

5. When installing insulation where no stud wall is intended, or where there are concerns about the adhesion of the board to the wall, it is advisable to use masonry screws and EIFS washers or IDP insulation anchors to fasten the insulation directly to the masonry wall.

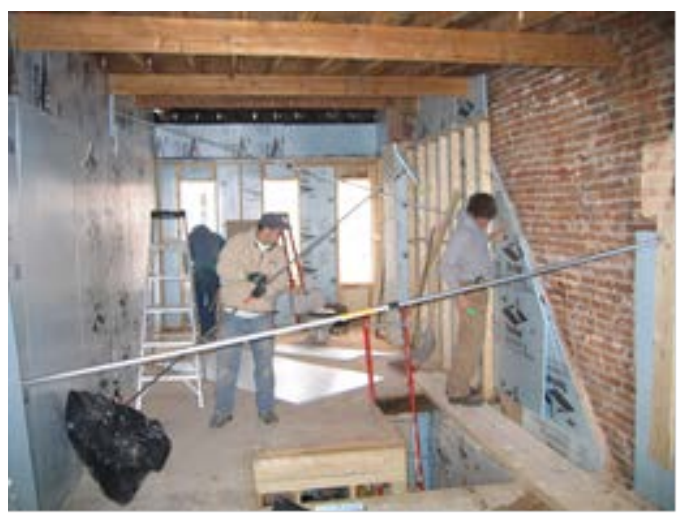

Figure 11. Bracing insulation on opposite walls

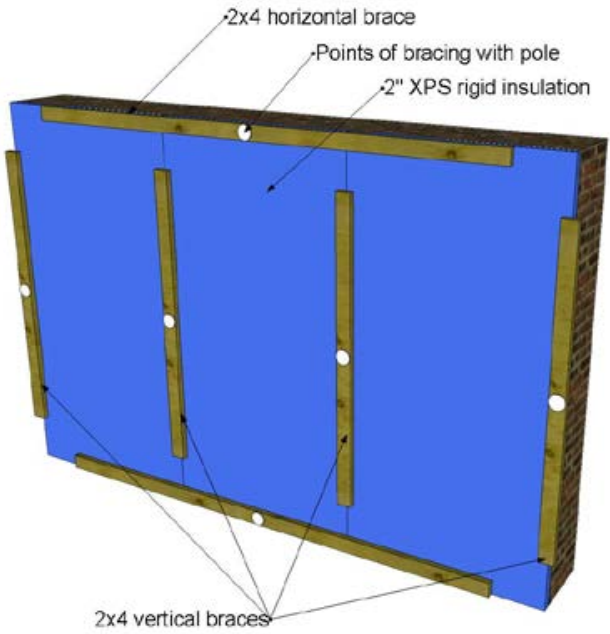

Figure 12. Board bracing pattern 


\subsubsection{Sealing the Joints and Seams}

Once all the rigid insulation board has adhered to the wall (after 10 minutes or so of continuous applied pressure), the joints and seams must be sealed to create an effective, continuous air-barrier.

1. Tape over all seams that are LESS that $1 / 8$ " wide. Ideally, all the joints should be as tightly butted as possible.

2. Prepare low-expanding foam sealant and applicator gun as per the manufacturer's instructions.

3. Fill all cracks, joints and seams GREATER than $1 / 8$ " wide with low-expanding foam. Use foam to seal all penetrations through the insulation board.

4. Allow foam to cure. Foam is usually tack-free in

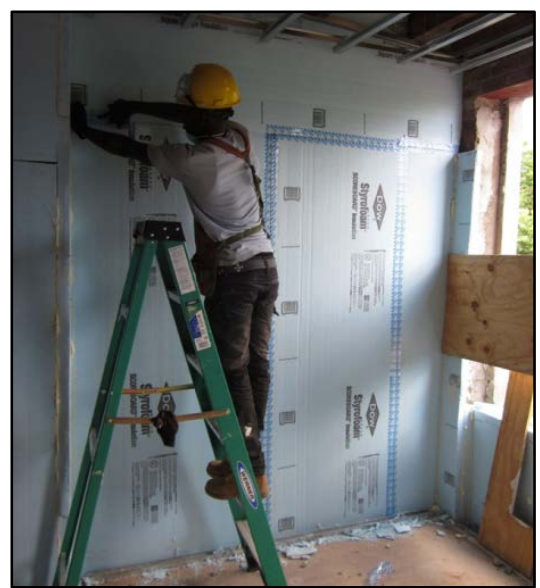

Figure 13. Tape over seams less than $1 / 8$ " wide 15 minutes and completely cured in 8 hours.

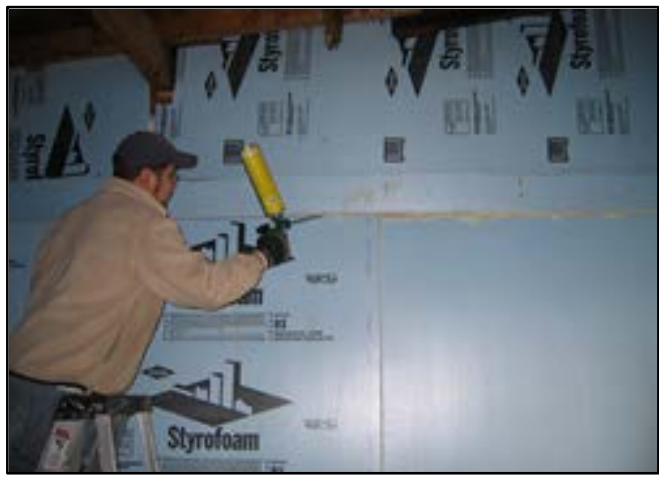

Figure 14. Use foam to seal all seams greater than $1 / 8$ " wide

\subsection{Joists, Sub Floors and Windows}

Insulating around joist, subfloors, and windows is a relatively straightforward task, with the only extra work required being the cutting of the XPS board.

\subsubsection{Where the Insulation Meets the Joists}

1. Measure around the joists and cut the insulation board to fit.

2. Apply adhesive to the pieces of insulation.

3. Slide insulation pieces into place and allow to adhere to wall.

4. Seal all gaps with low-expanding foam.

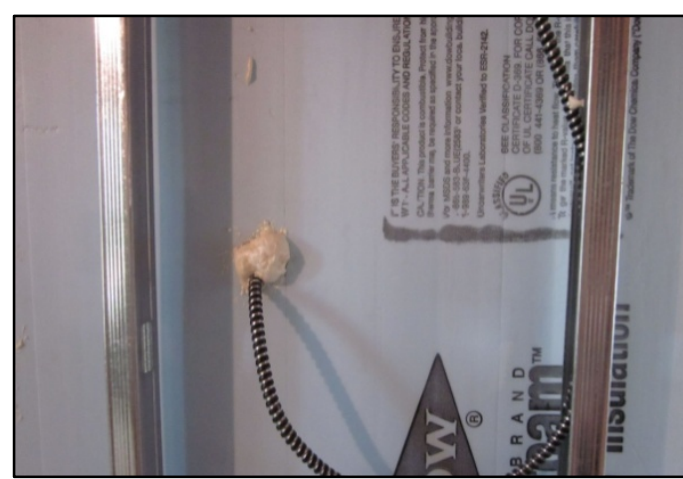

Figure 15. Seal all penetrations through the rigid board with foam

How to cut XPS board

1. Score the insulation on both sides with a utility knife

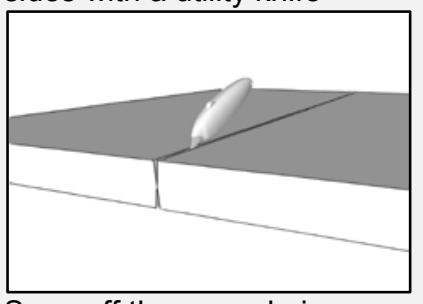

2. Snap off the scored piece

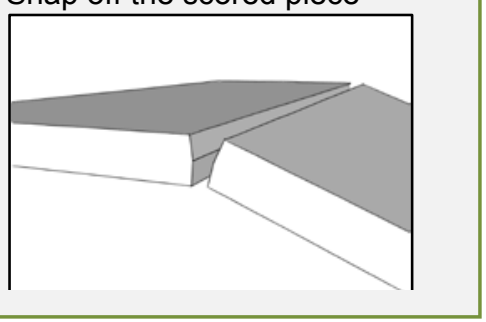




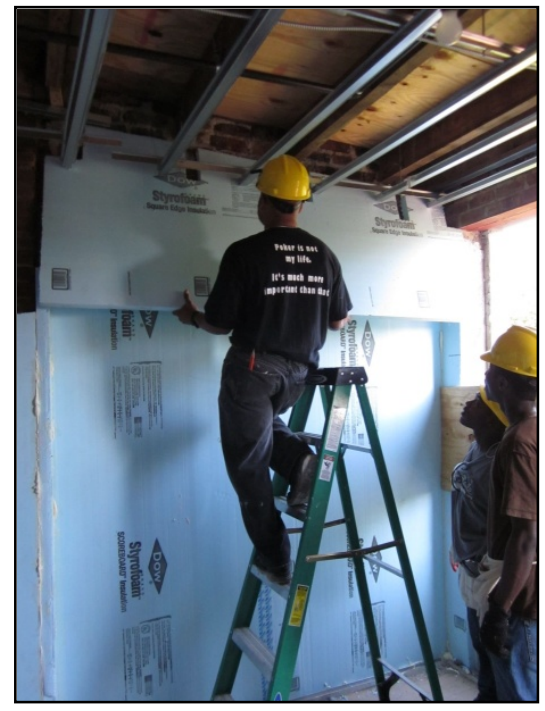

Figure 16. Install insulation from below

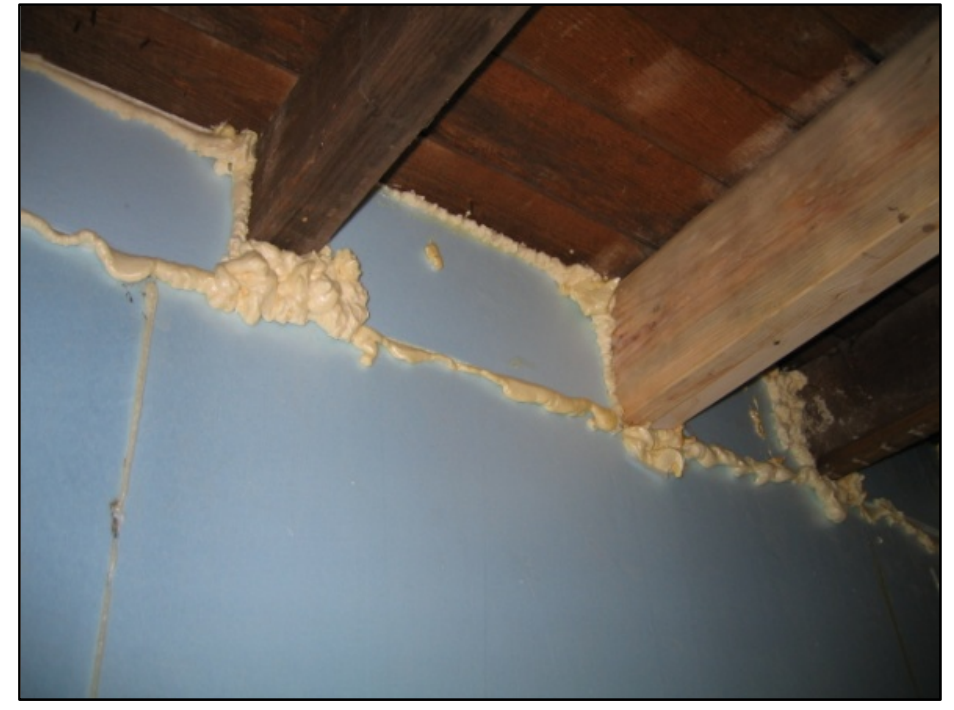

Figure 17. Seal all seams with low-expanding foam

\subsubsection{Where the Insulation Meets the Sub-floor}

The process for installing the insulation where the sub-floor is cut away from the brick wall is almost identical to the process for insulating around joists.

1. Measure around the joists and cut the insulation board to fit.

2. Apply adhesive to the pieces of insulation.

3. Slide insulation pieces into place from above/below and allow to adhere to wall.

4. Seal all gaps with low-expanding foam.

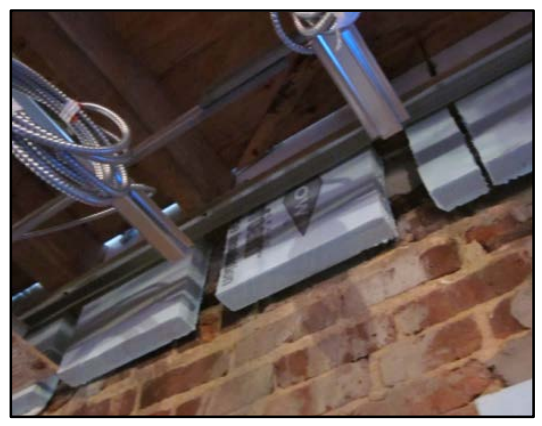

Figure 18. Rigid insulation extends past the sub-floor when installed from above

For multifamily construction, the requirements for rated assemblies between floors preclude this process. Typically, some type of wood or gypsum board will be used to terminate the wall assembly between floors.

\subsubsection{Where the Insulation Meets a Window}

When insulating walls in which the window is being replaced, follow these steps:

1. Ensure proper window flashing is installed and window sill is properly pitched.

2. Measure around the window opening and cut insulation board to fit.

3. Install the insulation.

4. Seal the rigid insulation to the window buck with low-expanding foam sealant or caulk.

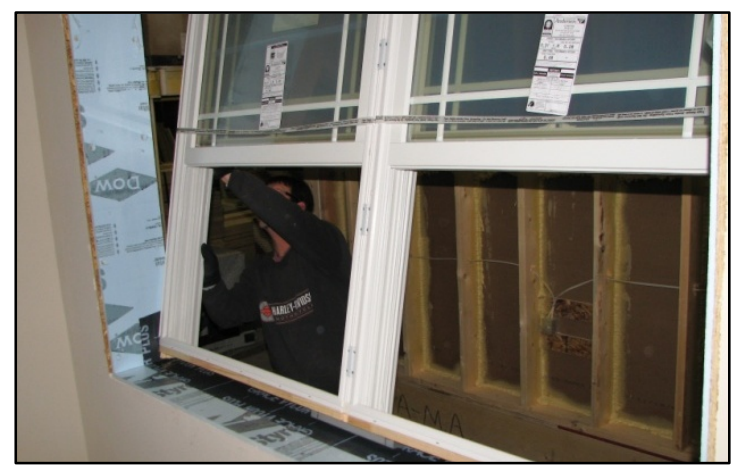

Figure 19. Installing a window after installing insulation and flashing. XPS insulation was placed between the window buck and the interior jamb extension (not yet installed) of this modular home. 
5. Install the window.

6. Seal the gap between the buck and window jamb with low-expanding foam sealant or caulk.

\subsubsection{Where the Insulation Meets an Existing Window}

When insulating walls that contain existing windows, it is important to keep in mind that the proper window drainage must be addressed first. This may require windows to be temporarily pulled/removed to allow for the installation of pan flashing.

1. Seal any existing small gaps between the brick and window buck with low-expanding foam sealant or caulk.

2. Cut and install interior rigid insulation so that it covers the existing window buck.

3. The interior stud wall should be framed flush to the rigid insulation edge (flush with buck).

4. Install an interior jamb extension to cover the exposed edge of the rigid insulation and stud framing. The jambs of the windows/doors should be extended to be flush with the interior face of the drywall.

5. Install drywall so that it butts up against the interior jamb extension. Seal gap with caulk.

6. Install window trim to cover butt joint of jamb extension to drywall.

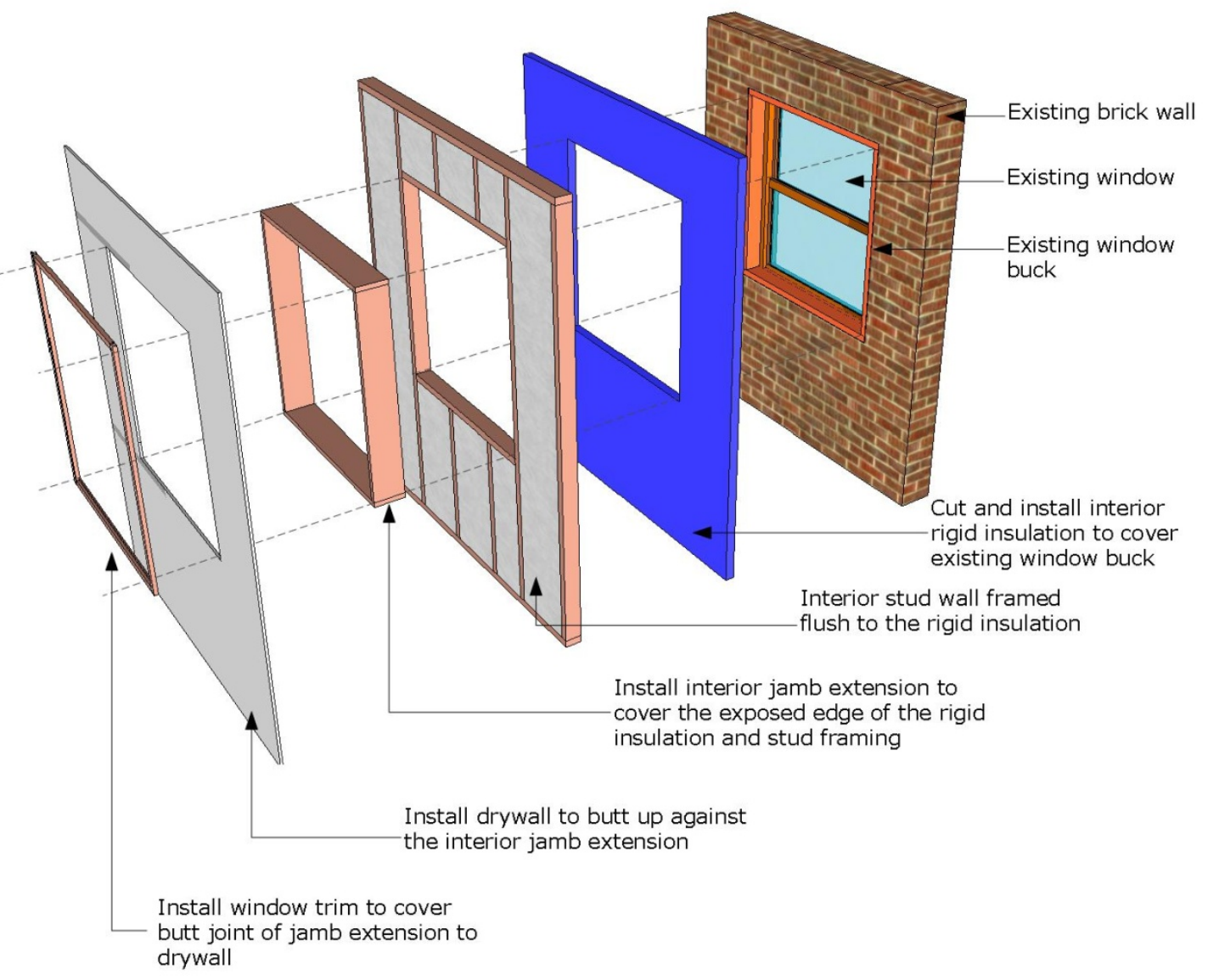

Figure 20. Insulating around an existing window 


\subsection{Framing the Stud Wall and Finishing}

To be compliant with code, and to negate the risk of a fire (polystyrene is flammable), the insulation cannot be exposed to interior conditions except in special cases (2009 IRC Section R316.4). Insulated walls are usually finished with a stud frame and drywall on the inside, which provides the homeowner or builder/contractor with the advantage of wall cavity space where further insulation can be installed if necessary. In special cases, insulation is finished by directly laminating the drywall on to it and skipping the framed stud wall, in cases like insulating around an existing fireplace.

\subsubsection{Framing Stud Walls After Insulation is Installed}

1. When studding out the walls, press the wood up against the rigid insulation. If the wall is too far out of alignment, place the wall as close as possible while still maintaining a straight wall profile.

2. Fill stud wall cavities with insulation if necessary.

3. Install drywall.

\subsubsection{Installing Insulation Behind Existing Stud Wall}

Rigid insulation can be installed after the walls are studded out, though the increased labor and longer install times associated with installing rigid XPS insulation behind an existing stud wall may decrease its cost effectiveness as a strategy.

1. If a wall has already been studded out, cut pieces of rigid insulation to a workable size so that they can be slid in behind the stud wall. This is a cumbersome and time consuming process, and may negate the costeffectiveness of installing rigid insulation under these conditions. For conditions involving existing stud walls, spray polyurethane foam insulation is a better strategy.

2. Fill stud wall cavities with insulation if necessary.

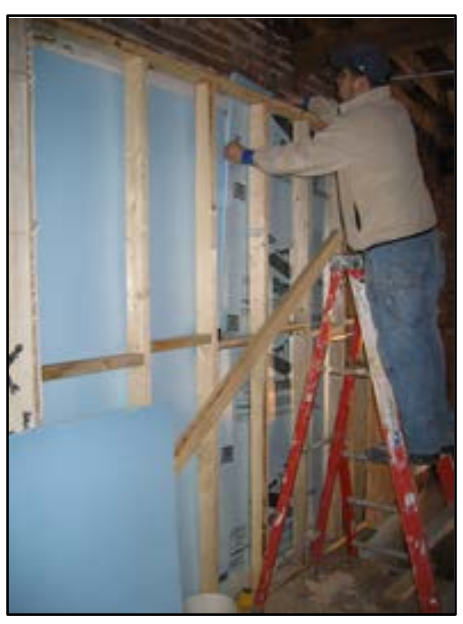

Figure 21. Slide insulation in behind existing stud wall

\section{Critical Takeaways}

- The key to the success of installing rigid insulation is the proper sealing of all joints, seams and cracks - creating a tight air/water barrier.

- The insulation can NEVER be exposed to ambient conditions on the inside. A thermal ignition barrier, such as drywall, MUST be installed to be compliant with code. 


\subsection{Combustion Safety Testing}

It is important to assess combustion appliances in the home and any potential safety issues associated with them. Adding rigid insulation in this manner can result in different pressure patterns within a home that can potentially alter combustion venting and draft. A brief overview of recommended safety precautions is provided here. It may be appropriate to consult more detailed program guidelines or to refer to BPI's "Technical Standards for the Building Analyst Professional."

\subsubsection{Measure Carbon Monoxide (CO) Concentrations}

Measuring ambient levels of carbon monoxide in the home is simple and can identify potentially hazardous situations. If ambient $\mathrm{CO}$ levels are extremely high, work should not proceed until the problem is corrected. It may also be appropriate to measure $\mathrm{CO}$ levels in the flue or exhaust from appliances (usually a different instrument is required). If CO concentrations in exhaust are high, it may be appropriate to have a qualified contractor adjust or tune the equipment to correct the problem.

Table 6. Exposure Limits for Carbon Monoxide (CO) ${ }^{1}$

\begin{tabular}{c|c}
\hline Agency / Organization & Maximum CO Concentrations \\
\hline $\begin{array}{c}\text { Occupational Safety and Health } \\
\text { Administration (OSHA) }\end{array}$ & $\begin{array}{c}50 \mathrm{ppm} \text { as an 8-hour time-weighted } \\
\text { average }\end{array}$ \\
$\begin{array}{c}\text { National Institute for Occupational Safety and } \\
\text { Health (NIOSH) }\end{array}$ & $\begin{array}{c}35 \mathrm{ppm} \text { as an 8-hour time-weighted } \\
\text { average AND 200 ppm at any time }\end{array}$ \\
$\begin{array}{c}\text { American Conference of Governmental } \\
\text { Industrial Hygienists (ACGIH) }\end{array}$ & $\begin{array}{c}\text { ppm as an 8-hour time-weighted } \\
\text { average for a 40-hour work week. }\end{array}$ \\
\hline
\end{tabular}

\subsubsection{Spillage Tests}

"Spillage" is the term used to describe the situation when a proper draft is not established in the flue pipe or chimney; the flue gases come "spilling" back down the flue and into the house. Spillage may be caused by pressure imbalances within the house and/or improper venting. Since flue gases can contain significant amounts of moisture and carbon monoxide, spillage can result in dangerous and unhealthy conditions.

Check for spillage by turning the appliance on and using a smoke stick, glass, or mirror to verify that there is negative draft around the draft diverter (i.e. flue gases are flowing up — not down - the flue) that is established within one minute of the burner firing. It is not unusual for some appliances (especially water heaters) to spill temporarily on startup. This is because the chimney needs to heat up before a proper draft is established. Spillage that occurs under normal building operating conditions should be addressed immediately. This is a serious health and safety risk for the

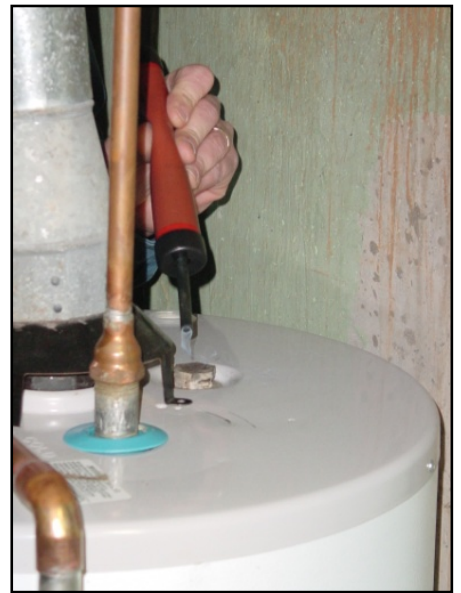

Figure 22. Spillage testing of an atmospherically vented, natural gas water heater

\footnotetext{
${ }^{1}$ http://www.osha.gov/SLTC/healthguidelines/carbonmonoxide/recognition.html
} 
occupants. Spillage may also be checked under simulated "worst-case" conditions as described in Section 4.5.4 below.

\subsubsection{Measure Draft}

Draft is measured by taking a pressure measurement in the flue pipe approximately 12 " downstream of the draft diverter. Draft should be measured under steady state conditions (usually after 5-10 minutes of operation). Acceptable draft is dependent on the outside temperature and height of the flue stack. Typical ranges are shown in Table 7.

Table 7. Typical Draft Requirements for Combustion Equipment from BPI's "Technical Standard for the Building Performance Professional"

\begin{tabular}{c|c}
\hline Outdoor Temperature $\left(\mathbf{T}_{\text {out }}{ }^{\circ} \mathbf{F}\right)$ & Minimum Acceptable Draft (Pa) \\
\hline$<10$ & -2.5 \\
$10-90$ & $\left(\mathrm{~T}_{\text {out }} / 40\right)-2.75$ \\
$>90$ & -0.5 \\
\hline
\end{tabular}

\subsubsection{Worst Case Depressurization}

It is often recommended that combustion safety tests be conducted under "worst case" conditions. Since testing only gives us a snapshot of how the system is performing on a particular day under the current conditions, it does not necessarily assure us that the system might not fail at another time under different conditions. Using the worst-case approach, contractors are better assured that combustion appliance failures will not occur after they leave the house.

To set up worst case conditions, first identify the combustion appliance zone (CAZ) and set up a manometer to measure the pressure in the CAZ with reference to (wrt) outside. Make changes to the house configuration using the following checklist, and check the CAZ pressure wrt outside at each step. Keep making changes until you have achieved the most negative pressure possible in the CAZ.

Checklist for Establishing Worst-Case Depressurization:

- Turn on exhaust fans (bath fans, range hoods, etc), including clothes dryers

- Turn on/off the air handler fan

- Open/close door to the CAZ (in some houses open will be worst case, in others the door should be closed for worst case)

\begin{tabular}{|c|c|c|c|}
\hline \multicolumn{3}{|c|}{ Table 8. BPI's CO Action } \\
Levels \\
\begin{tabular}{|c|c|c|c|}
\hline $\begin{array}{c}\text { CO } \\
\text { Level } \\
\text { (ppm) }\end{array}$ & And/Or & $\begin{array}{c}\text { Spillage and } \\
\text { Draft }\end{array}$ & $\begin{array}{c}\text { Retrofit } \\
\text { Action }\end{array}$ \\
\hline $0-25$ & And & pass & proceed \\
\hline $26-100$ & And & pass & $\begin{array}{c}\text { recommend } \\
\text { fix }\end{array}$ \\
\hline $26-100$ & And & $\begin{array}{c}\text { fails } \\
\text { (worst case) }\end{array}$ & $\begin{array}{c}\text { recommend } \\
\text { fix }\end{array}$ \\
\hline $100-400$ & Or & $\begin{array}{c}\text { fails } \\
\text { (natural } \\
\text { case) }\end{array}$ & $\begin{array}{c}\text { stop work, } \\
\text { fix }\end{array}$ \\
\hline$>400$ & And & pass & $\begin{array}{c}\text { stop work, } \\
\text { fix }\end{array}$ \\
\hline$>400$ & And & $\begin{array}{c}\text { fails } \\
\text { (any case) }\end{array}$ & $\begin{array}{c}\text { shut off fuel, } \\
\text { fix }\end{array}$ \\
\hline
\end{tabular}
\end{tabular}

- Open/close interior doors

Once you have established the worst-case scenario, turn on the combustion appliances, one at a time, starting with the smallest. Check each appliance individually for spillage and draft. If more 
than one appliance shares a chimney, also conduct the test with both appliances operating simultaneously.

\subsubsection{Remedies for Combustion Problems}

If combustion problems are identified, they should be immediately addressed by a qualified contractor. While safe operation can be achieved by providing outdoor air and adjusting appliances properly, installing sealed-combustion appliances is very often the best remedy for providing reliable, safe, and efficient space heating and water heating. Strong consideration should be given to this strategy.

In homes with any combustion appliances, carbon monoxide sensors/alarms are required by many codes. These can help alert occupants to serious combustion problems.

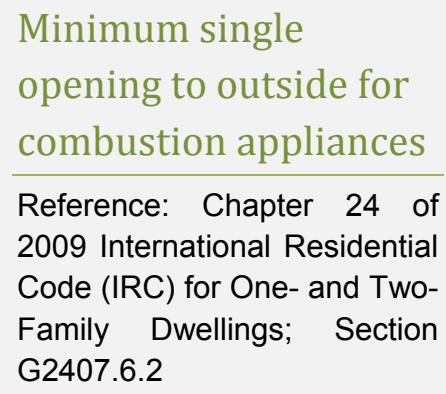




\section{Appendix A: Measure Implementation Checklist}

The nature and scope of brick masonry wall insulating efforts can vary substantially. Based on these guidelines, the checklist below is presented as a potential framework (though not an exhaustive resource) for installing rigid insulation on the interior of a brick masonry wall.

1. Inspect the interior of the wall for significant risks. Are any of the following present?

\begin{tabular}{|l|c|c|}
\hline Cracked, Loose and Spalled Bricks & YES & NO \\
\hline Cracks/Deterioration in mortar & YES & NO \\
\hline Cracks/Deterioration in sealant & YES & NO \\
\hline Efflorescence & YES & NO \\
\hline Staining & YES & NO \\
\hline Mold or Lead paint & YES & NO \\
\hline Moisture Problems & YES & NO \\
\hline $\begin{array}{l}\text { Occupants with health conditions who may be } \\
\text { sensitive to work being done }\end{array}$ & YES & NO \\
\hline
\end{tabular}

If the answer is YES to any of these or if other serious risks are identified, do not proceed with work until the risks have been addressed. If the wall is plastered, REMOVE plaster and inspect the wall again.

\section{Cleaning the Wall}

Clean the wall of all debris, plaster and nails. Then inspect it again.

\begin{tabular}{|l|c|c|}
\hline Is the wall free of debris, plaster and nails? & YES & NO \\
\hline Are any of the risk issues from Item 1 present? & YES & NO \\
\hline
\end{tabular}

If any risks are present, rectify before proceeding with the installation of insulation.

\section{Moisture Penetration and Sealing}

\begin{tabular}{|l|c|c|}
\hline Are there cracks in the brick and mortar greater than $0.02 "$ & YES & NO \\
\hline Are there any visible signs of moisture penetration? & YES & NO \\
\hline
\end{tabular}

- If there are cracks in the brick greater than 0.02 ", rectify before proceeding.

- If there are no visible cracks, but evidence of moisture penetration, apply a liquid air/water barrier to the surface

- Allow the applied coating to cure as per manufacturer's instructions.

- If there are no cracks or visible signs of moisture penetration, it is not necessary to apply the air/water barrier coating.

\begin{tabular}{|l|c|c|}
\hline Has the air/water barrier coating cured? & YES & NO \\
\hline
\end{tabular}




\section{Installation of Complete Boards of Insulation}

- Prepare adhesive gun as per manufacturer's instructions.

- Dry-fit the insulation to the wall. Use full 4'x8' sheet as far as possible. Place it flush to the floor.

- Apply a $1 / 2$ " bead of adhesive along the perimeter of the board, and as an ' $\mathrm{X}$ ' across the center.

- Apply the rigid insulation to the wall surface.

- Apply continuous pressure for about 5 minutes. DO NOT move the board around as it will reduce the adhesion of the foam adhesive.

- Place a $2 \times 4$ brace against the seam of the rigid insulation boards. If a narrow width, use an extension pole to hold the wood and rigid insulation in place for at least 5 minutes. Do both sides of the units at the same time as this will speed the process up by providing support to both pieces of rigid insulation.

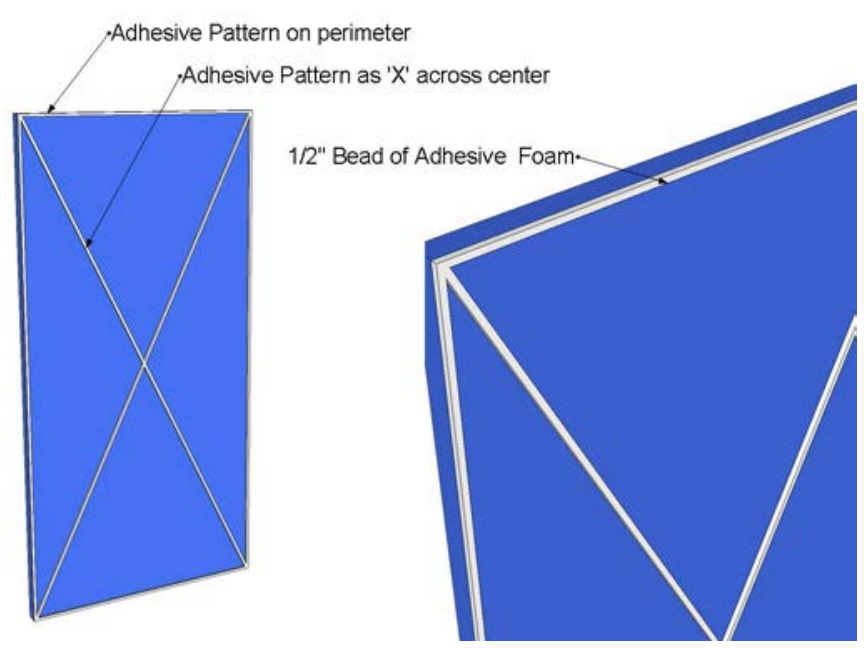

Adhesive Application Pattern

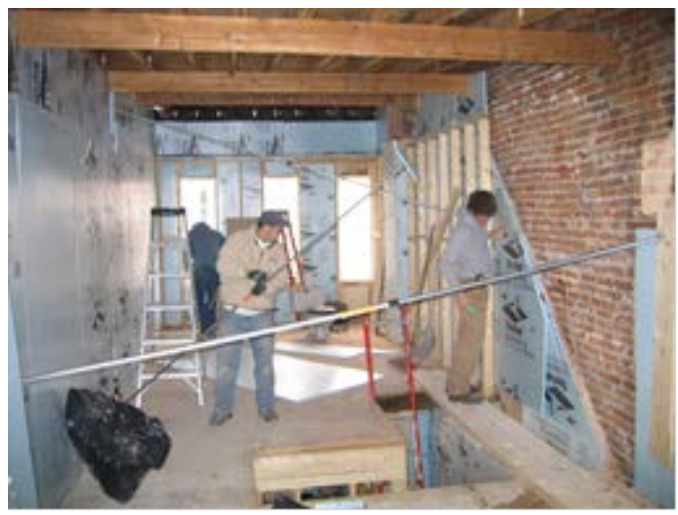

Bracing opposite sides with extension poles

Pole and board bracing pattern 
Has all the wall area that can be covered with full-size boards been covered?

Have all the installed boards been braced for at least 5 minutes?

\section{Installation of Cutouts around the Joists and Sub-floor}

- Measure joists and sub-floor cutouts. The cutouts should extend at least 6" above the ceiling plane and below the floor.

- Cut insulation sheets to fit. (To cut insulation - mark with pen, score with utility knife and then snap).

- Apply adhesive as before to insulation sheets.

- Slide sheets to fit into joists from below.

- Slide sheets into gap between sub-floor and wall from above.

- Brace sheets and apply continuous pressure for at least 5 minutes

\begin{tabular}{|l|l|l|}
\hline Have the insulation boards adhered to the wall? & YES & NO \\
\hline
\end{tabular}

\section{Taping and Sealing Joints}

- Prepare foam sealant gun as per manufacturer's instructions.

- Fill all cracks, seams and joints GREATER than 1/8" wide.

- The following areas should be filled:

$\circ$ seam between the floor and the rigid insulation

- space between adjoining pieces of rigid insulation

$\circ$ area around the floor joists

○ top edge of rigid insulation that extends into the ceiling area

- overlap of insulation, if plaster cannot be removed

- any other areas where brick is exposed and rigid insulation cannot be utilized.

- Tape over all seams and joints LESS than $1 / 8$ " wide

\begin{tabular}{|l|c|c|}
\hline Have all cracks, seams and joints been sealed? & YES & NO \\
\hline
\end{tabular}

\section{Insulating behind an existing stud wall}

\begin{tabular}{|l|c|c|}
\hline Is there an existing stud wall? & YES & NO \\
\hline
\end{tabular}

- Cut insulation boards into pieces small enough to slide behind the studs.

- Apply adhesive as before to insulation sheets

- Slide sheets to fit into joists from below.

- Slide sheets into gap between sub-floor and wall from above.

- Brace sheets and apply continuous pressure for at least 5 minutes.

- Tape and seal all cracks, joints and seams.

- Install insulation in stud wall cavity if necessary.

- Install drywall. 
Have the insulation boards adhered to the wall?

Have all cracks, seams and joints been sealed?

\section{Framing a stud wall}

- Press wood up against rigid insulation.

- If masonry wall is out of alignment, place wall as close to insulation as possible while still maintaining a straight profile.

- Install insulation in stud wall cavity if necessary.

- Install drywall.

\section{Installing when no stud wall is intended (Like around fireplaces)}

- Install insulation as before.

- Use masonry screws to adhere the insulation structurally to the masonry.

- Apply construction adhesive to drywall.

- Laminate drywall directly to insulation.

\section{Insulating around a window}

\begin{tabular}{|l|c|c|}
\hline Is there an existing window? & YES & NO \\
\hline
\end{tabular}

If there is an existing window in the wall:

- Seal any existing small gaps between the brick and window buck with low-expanding foam sealant or caulk.

- Cut and install interior rigid insulation so that it covers the existing window buck.

- The interior stud wall should be framed flush to the rigid insulation edge (flush with buck).

- Install an interior jamb extension to cover the exposed edge of the rigid insulation and stud framing. The jambs of the windows/doors should be extended to be flush with the interior face of the drywall.

- Install drywall so that it butts up against the interior jamb extension. Seal gap with caulk.

- Install window trim to cover butt joint of jamb extension to drywall.

If there is no existing window in the wall:

- Ensure proper window flashing is installed and window sill is properly pitched.

- Measure around the window opening and cut insulation board to fit.

- Install the insulation.

- Seal the rigid insulation to the window buck with low-expanding foam sealant or caulk.

- Install the window.

- Seal the gap between the buck and window jamb with low-expanding foam sealant or caulk. 


\section{References}

ICC (2009). International Energy Conservation Code. Washington, DC: International Code Council.

ICC (2009). International Residential Code. Washington, DC: International Code Council.

BIA. (1997)."Technical Notes 4 - Heat Transmission Coefficients of Brick Masonry Walls." Technical Notes on Brick Construction. Reston, VA: The Brick Industry Association. Accessed June 11, 2012: http://www.gobrick.com/Portals/25/docs/Technical\%20Notes/TN4.pdf.

Bureau of Labor Statistics, U.S. Department of Labor. (2011). AVERAGE ENERGY PRICES IN NEW YORK - NORTHERN NEW JERSEY - FERBRUARY 2012, NYLS-7522. Accessed June 11, 2012: http://www.bls.gov/ro2/avgengny.pdf.

"Retrofit Measures for Wall Sheathing." National Residential Efficiency Measures Database. National Renewable Energy Laboratory, Accessed. December 18, 2011 : http://www.nrel.gov/ap/retrofits/measures.cfm?gId=1\&ctId=44

BIA.(2005). "Technical Notes 46 - Maintenance of Brick Masonry." Technical Notes on Brick Construction. Reston, VA: The Brick Industry Association. Accessed June 11, 2012: http://www.gobrick.com/Portals/25/docs/Technical\%20Notes/TN46.pdf.

Mack, Robert, and Speweik, John. National Park Service. Technical Preservation Services. Preservation Briefs - Repointing Mortar Joints in Historic Masonry Buildings. 1998. http://www.nps.gov/hps/tps/briefs/brief02.htm.

BIA. (2005) " Technical Notes 7A -Water Penetration Resistance - Materials." Technical Notes on Brick Construction. Reston, VA: The Brick Industry Association. Accessed June 11, 2012: http://www.gobrick.com/Portals/25/docs/Technical\%20Notes/TN7A.pdf

BIA. (2006)" Technical Notes 20 -Cleaning Brickwork." Technical Notes on Brick Construction. Reston, VA: The Brick Industry Association. Accessed June 11, 2012: http://www.gobrick.com/Portals/25/docs/Technical\%20Notes/TN20.pdf.

Merrigan, M.. "Efflorescence: Cause and Control." The Masonry Society Journal , 1986.

Straube, J.F., Ueno, K., and Schumacher, C.J.. Building Technologies Program, U.S. Department of Energy. (2012). Measure Guideline: Internal Insulation of Masonry Walls. (to be published summer 2012)

BPI. (2005). Technical Standards for the Building Analyst Professional. Malta, NY: Building Performance Institute. Accessed April 8, 2011: http://www.bpi.org/Web Download/BPI Standards/Building Analyst Professional 2-28-05nNC-newCO.pdf.

Gromicko, N., London, R., and Shepard, K. "Efflorescence for Inspectors.” Accessed June 11, 2012: http://www.nachi.org/efflorescence.htm. 
Mack, R. and Speweik, J. (1998). Repointing Mortar Joints in Historic Masonry Buildings. National Park Service. Accessed May 7, 2012:

http://www.nps.gov/history/hps/tps/briefs/brief02.htm. 


\section{U.s. DEPARTMENT OF Energy Efficiency \& ENERY Renewable Energy}

